\title{
Ethnomedicinal knowledge of a marginal hill community of Central Himalaya: Diversity, usage pattern and conservation concerns
}

\section{S. N. Ojha}

Govind Ballabh Pant National Institute of Himalayan Environment and Sustainable Development

\section{Deepti Tiwari}

Govind Ballabh Pant National Institute of Himalayan Environment and Sustainable Development

Aryan Anand

Govind Ballabh Pant National Institute of Himalayan Environment and Sustainable Development

R.C. Sundriyal ( $\nabla$ sundriyalrc@yahoo.com)

G.B. Pant Institute of Himalayan Environment and Development

\section{Research}

Keywords: Ethnomedicinal plants, Traditional knowledge, Indigenous people, Ailments, Public health, Bageshwar, Uttarakhand

Posted Date: April 13th, 2020

DOI: https://doi.org/10.21203/rs.2.19077/v2

License: @ (i) This work is licensed under a Creative Commons Attribution 4.0 International License. Read Full License

Version of Record: A version of this preprint was published at Journal of Ethnobiology and Ethnomedicine on May 24th, 2020. See the published version at https://doi.org/10.1186/s13002-020-00381-5. 


\section{Abstract}

Background Indigenous communities use wild plants to cure human ailments since ancient times, such knowledge has significant potential for formulating new drugs and administering future health care. Considering this the present study was undertaken to assess use value, diversity, and conservation concerns of medicinal plants used in traditional herbal care system of a marginal hill community in Bageshwar district of Uttarakhand in the Central Himalayan region of India.

Methodology Extensive surveys were made in 73 villages to gather information on ethnomedicinal use of plant species used in traditional herbal healing system. A total of 100 respondents were identified (30 herbal healers called 'Vaidyas' and 70 nonhealers/natives) and interviewed using semi-structured questionnaires, target interviews and group discussion. Some important indices such as the use value index (UV), relative frequency citation (RFC), cultural importance index (Cl), and informant consensus factor ( $F$ ic ) were calculated for the medicinal plants included in the present study.

Result It was recorded that the community use a total of 70 species with 64 genera and 35 families for curing various ailments. Family Lamiaceae recorded maximum number of medicinal plants. 21 species used most extensively in traditional health care system. The major parts of the identified plants used for treatment of various ailments were root/rhizome and leaf. The most common methods used for preparation of these plants were decoction and infusion. Ocimum basilicum L., Cannabis sativa L., Citrus aurantifolia (Christm) Sw., Curcuma longa L.and Setaria italic L. had the highest rate of use report. RFC value ranged between 0.03 to 0.91 with highest values for Setaria italica, Zingiber officinale, Ocimum basilicum, and Rephanus sativus. The traditional knowledge is passed verbally to generations and needs to be preserved for the future bio-prospecting of plants that could be a potential cure to any future disease.

Conclusion In recent years the community has access to modern hospitals and medicinal facilities, although a considerable number still prefer medicinal plants for curing select ailments. It is suggested that these ethnomedicial species need to be screened and evaluated further for their effectiveness for pharmacological activity. Also, significant efforts are required to conserve traditional knowledge and natural habitats of wild medicinal plants.

\section{Introduction}

Medicinal plants have been utilized for the treatment of various diseases since ancient time, thus form an important element of aboriginal curative systems. The Indian Rishis first documented the use of medicinal plants in the form of Samhitas. Charak Samhita (1000-800BC) and Shushrut Samhita (800-700BC) by Maharshi Charak and Maharshi Shashurut respectively, are the baselines of the Indian Medicinal System. Maharshi Charak mentioned over 500 medicinal plants, out of which 340 plants used in the production of herbal medicine[1-2]. AYUSH (i.e. Ayurveda, Unani, Siddha, and Homeopathy) is another traditional Indian healthcare system that is considered a great knowledge-based in herbal medicines. Ayurveda reports over 2000 medicinal plant species, Siddha 1121 plant species, Unani 751 species, and homeopathy 422 species[3]. Nearly 70-80\% population worldwide still relies on traditional medicinal systems for their primary healthcare because of their effectiveness, cultural preferences, and lack of modern healthcare alternatives[45]. The global demand for herbal medicine continues to increase over the past few decades. The earlier studies stated that out of $2,50,000$ flowering plants in the world only less than $10 \%$ have been examined successfully for their medicinal potency and still, $90 \%$ remains unexplored[2]. In recent times there is an increased interest regarding use of medicinal plant to develop new drugs and medicines for fulfilling the demand of growing population[6-8]. Therefore information on plants of ethnomedicinal importance holds high potential. Uttarakhand Himalaya is a mountainous region in the northern India that has unique geography, rich biological resources, cultural heritage and diverse climatic conditions which supports the highest number of medicinal plant species[9]. Over two-third population live in rural areas and depend on diverse natural resources to fulfil their need of food, fuel, fodder, timber, medicine, etc. Communities use large variety of medicinal plants for treating diverse ailments[10-11]. However, it is strongly being realized that the indigenous knowledge related to herbal medicines is continuously being eroded despite of high significance to humanity. The subject needs further research such as documentation of potential medicinal species, analyzing their active constituents, clinical trials for validations, and developing new drugs and medicines[1,4,8-12]. Considering this the present study was undertaken. We hypothesize that sustainable management and conservation of medicinal plants can be achieved when information about medicinal plants that are utilized for treating ailments and traditional herbal practices within particular areas are available. Such information is strongly desired to be preserved from being lost for the use of both present and future generations. For the purpose of this study we selected marginal community and local herbal practitioners (Vaidyas) of Bageshwar district in Uttarakhand state in north India and documented ethnomedicinal plant diversity and traditional medicinal practices being used by them. Efforts are also made to scientifically validate 
and interpret the data using several indices such as Relative Frequency Citation (RFC), Use report (Categorical and disease-based), Cultural Importance Index $(\mathrm{Cl})$, and Informant Consensus Index $\left(\mathrm{F}_{\mathrm{ci}}\right)$ so as to verify the homogeneity, importance, cultural similarity of the medicinal plants in communities. It is expected that the qualitative and quantitative information generated from this study will have immense utility for conservation and sustainable utilization of medicinal plants as well as for managing traditional health care system.

\section{Materials And Methods}

\section{Study area}

The aim of this study was to investigate the medicinal species used by the marginal hill community living in remote and high-altitude areas where medical healthcare facilities are not easily available. These practices are being used since eternity descended from the inherited knowledge of the locals and indigenous population of Uttarakhand. The study was carried out at Bageshwar district (geographical area $1687.8 \mathrm{~km}^{2}$ ) of Uttarakhand State and lies between latitudes $29^{\circ} 42^{\prime} 40^{\prime \prime}$ to $30^{\circ} 18^{\prime} 56^{\prime \prime} \mathrm{N}$ and longitudes $79^{\circ} 23^{\prime}$ to $80^{\circ} 10^{\prime} \mathrm{E}$ (Fig.1). The district is situated on the confluence of Gomti river and Saryu river which is a tributary of Kali river. It is bounded by Almora district in the southwest, Chamoli district in the north and northwest, and Pithoragarh district in the east. Administratively the districtis divisible into four Tehsils, viz. Bageshwar, Kapkot, Kanda (Sub-tehsil) and Garur, and three blocks, viz. Bageshwar, Garur and Kapkot. There are 947 revenue villages, out of which 874 villages are inhabited and 73 villages are uninhabited. As per the 2011 census the total population of Bageshwar district is 270,332 . 259,898 (male $48 \%$, female $52 \%$ ) with $96 \%$ living in the rural areas.

The community of the area divided into 3 categories viz., General, Scheduled Class (SC), Scheduled Tribe (ST), and majority of them involved in primary sector (agricultural activities), while some also work in secondary and tertiary sectors, such as private works, businesses, govt. jobs etc. As such the community is highly marginal with small and scattered land holdings, low production and low income; therefore, highly dependent on natural resources. Male population out-migrates to earn better livelihoods that lead to continuous increase in fallow lands and culturable waste lands.

\section{Data collection:}

The study was conducted in 39 villages covering Garur-Ganga valley (23 villages) and Saryu valley (16 villages) of Garur and Kapkot Blocks during 2016-2018. To fulfil the objectives of the study, extensive field visits were made to gather information from traditional herbal healers (Vaidyas) and indigenous people using semi-structured questionnaires, target interviews, visual interpretation through snowball methodology. A total of 100 respondents were randomly selected for the present study from both valleys, 37 being male and 63 female respondents. Of them 30 were Vaidyas (male 19, female 11). Female informants were given preference in view of their dominance in villages when selecting the population due to their dominancy in household and foraging sector. The age group of informants varied between 30 to 83 year although most of them vary between 50-65 years of age(Fig.2). The questionnaire contains information about the ethnomedicinal plants with their local name, parts used, habit, ailment treated by medicinal plants and mode of utilization of herbal formulation. Two general meetings and interviews were also organized at each valley with Vaidyas and natives. The documented medicinal plant species were collected and validated for identification using available literature[13-16],The specimens matched with the herbarium lodged in CCRAS-RARI, Tarikhet, Ranikhet, Uttarakhand (acronym RKT), which houses largest medicinal plant herbariums in the northern India. A few generally available species were matched with the plant database of Centre for SocioEconomic Development deposited at G.B. Pant National Institute of Himalayan Environment (GBP-NIHE), Almora, Uttarakhand.

\section{Ethno-botanical Analysis}

The information on ethnomedicinal important species were recorded including the local names of the species, habit, their uses in different forms, the part used in the medical practice, mode of administration and the condition of the plant (fresh or dry). The plants were classified into 12 main categories of ailments which were further divided into different respective sub-categories on the basis of disease and affected body part. The data were then statistically analyzed for different parameters. In order to enhance the indicative value of the ethnomedicinal study suitable quantitative methods and approaches were used in the form of indices, such as relative frequency of citation (RFC); use report (on the basis of illness, on the basis of taxa); cultural importance (Cl) and consensus factor of informants $\left(\mathrm{F}_{\mathrm{ci}}\right)$.

Use Report Values (UR) provides information on the total number of reported uses for each species. It is similar to the use-value of a species but for use report, the number of events (interviews) the process of asking one informant on one day about the uses they know 
for one species, is one because the respondents were interviewed only once. And response use values are broken down by the number of uses reported for each plant species part.

Use Value Index (UV) depicts the importance of each species for each informant and calculated by $U V=\sum U / N$ formula where $U$ is the number of uses quoted in each interview by $N$ number of informants. Use values are high when there are many useful reports for a plant representing its importance, and come within reach of to zero (0) when the use reports are low[17].

Relative Frequency Citation (RFC) index reveals the usage importance of a particular species used by different informants. The index is calculated by dividing the total number of informants referring to aparticular taxon with the total number of informants given $\left(R F C=F C_{\mathrm{s}} / M\right)$ Where $F C$ is the total number of informants that referred to the taxon and $N$ is the total number of informants[18].

Cultural Importance Index (CI) is estimated for each locality as the summation of Use-Report (UR) in every use category mentioned for a species in the locality divided by the total number of informants. This index provides an implication of the involvement of a particular taxon in the community and a greater value signifies that a particular is widely distributed amongst communities. A null value indicates non-existence of the species in the area. $\mathrm{Cl}$ is calculated as: $\mathrm{Cl}=U R / N$ where $U R$ is the total number of use reports for each species in every category of illness mentioned and $N$ is the total number of informants[19].

Informant consensus Factor $\left(F_{i c}\right)$ is used to test the consistency of information knowledge in treating a particular illness category. The values obtained, are near one (1) if there lie well-defined selection criteria in the community and/or if the information is exchanged between the informants. A value approaching zero (0) represents that the plants are chosen randomly and/or there is no information exchanged between the communities about their use. $F_{i c}$ is calculated as $F_{i c}=\left(N_{u r}-N_{t}\right) /\left(N_{u r}-1\right)$. Where $N_{u r}$ refers to the number of use reports for a particular use category and $N_{t}$ refers to the number of taxa used for a particular use category by all informants [20].

\section{Result And Discussion}

\section{Ethnomedicinal uses of plants and mode of practice}

The residents of different age groups were surveyed to assess ethnomedicinal uses of plant species (Fig. 2). The survey revealed that a total of 70 medicinal plant species varying from 35 families and 64 genera have been used by the inhabitants of 39 villages for different (Table 1). Family Lamiaceae recorded maximum species (8) followed by Asteraceae (6 species), Fabaceae (5 species), Rosaceae (4 species) and Apiaceae, Liliaceae, Ranunculaceae, Rutaceae, Zingiberaceae (3 species each). The remaining families were represented withjust one or two species. Almost all the species are widely used by the community. Of the total documented medicinal plant species the herbaceous habit (51 species) was most dominant life form, followed by the tree (10), shrub (7) and climbers (2 species)(Fig.3).

It was interesting to note that nearly $70 \%$ population still use prescription of Vaidyas for common ailments, although the Vaidyas were having an age of $>50$ years. The diseases cured by Vaidyas comprised fever, stomach problem, cough, cold, headache, etc. from centuries. The most common plant parts used was root/rhizome, followed by leaf, whole plant, seeds, fruits, flower, and bulb and latex (Fig. 4). The collection of plant part was very selective keeping into consideration the time of collection, plant matureness, and quantity of use thus ensuring a conservation approach. Vaidyas comprised sound knowledge and species-specific method of preparing drugs to cure various ailments (Table 2). Making decoction and ingestion was the most common modes of plant part use (Fig.5). Poultice and cooking were also favored for many medicinal plants. Another mode of application include cooking and making into powder (9.42\%), direct application (7.97\%), emulsion and infusion (5.80\%), and ointment (2.17\%) (Fig. 5). Decoction is most commonly used method to cure ailments in traditional herbal systems [38-42]. It is considered to extract all potential bioactive compounds after heating [43]. The pleasant taste of the herbal drug can be attuned by adding together honey or sugar [44]. Ingestion and poultice was also common after crushing and/or mixing the plant parts with some solvent for application as paste and band-aid. In skeletal, muscle and dermatological issues application of plant parts as ointment was most prevalent.

The community and Vaidyas identify each medicinal plants with a specific vernacular name. For example, Berginia ciliata is identified by the community with a local name'Pattharchatta' (stone destroyer) and it is used in curing kidney stone. Plantago ovate is called 'Jonkpuri' (jonk resembles worms) is used in the treatment of Ascaris and other worms. Viola betonicifolia named as 'Garur-Jadi'(Garur means eagle) and it is used as an antidote to treat snake bites. It is common that community identify a native name for species based on its local uses, ecology, physiology, anatomy, pharmacological activity, etc.[45]. 
It was recorded that the species were used to cure a total of 12 major ailments (Fig. 6). Most species were used for curing gastrointestinal and general health disorders. It was followed by species used for treating dermatological and respiratory problems.

Lamiaceae has been the most dominating family for ethnomedicinal uses in trans-Himalayan zone of Nepal [26] and Garhwal Himalaya in India as well [27]. Although the people in remote areas are still dependent on the traditional herbal cure system, it is being practiced by a few elderly people only. Young generation is not interested to take up this profession in view of minimal profit $[3,10,12]$. The common plant part in the present study is similar to other investigations [28-32]. The roots being the storage part of the plant it contains valuable bioactive compounds [33]. Apart from the root part, leaves also contain a high concentration of health-beneficial secondary metabolites, phytochemicals, and essential oils, which contribute significantly to phototherapy or treatment of various health disorders [34-37]. The study reports $60 \%$ more species than reported earlier for the area under investigation[21-25].

\section{Quantitative analysis of ethnomedicinal information}

Use value of important ethnomedicinal species was also calculated to depict number of uses reported by the informants related to the utility of a species for a specific ailment or different ailments (Table 1,3). Two forms of use reports were analyzed; the UR ${ }^{C}$ defines use of a particular species to cure specific ailments as reported by all the informants, while UR ${ }^{d}$ reports the sum of all the uses for a particular disease/ailment. Ocimum basilicum, Cannabis sativa, Citrus aurantifolia, Curcuma longa and Setaria italica have been top positioned in terms of use-reports and different ailments cured.

The usefulness of a species can be represented through its RFC value, which ranged 0.03 to 0.91 for different species (Table 1). Species with maximum RFC value were Setaria italica, Zingiber officinale, Ocimum basilicum, and Rephanus sativus which depict their higher use, while those with least value comprised Duchesnea indica and Thalictrum foliosum.

The Cultural importance index $\left(\mathrm{Cl}_{\mathrm{s}}\right)$ specifies the distribution and importance of species in traditional herbal system and the value ranged from 0.03 to 0.97 . A total of 21 species have been identified as most commonly used (Table 3). Ocimum basilicum, Cannabis sativa, and Citrus aurantifolia registered highest cultural importance in traditional herbal cure system. Low $\mathrm{Cl}$ values specify that these species are either least used or their use is declining up in traditional herbal cure system [49].

An analysis of Informant Consensus Factor $\left(F_{i c}\right)$ for 12 broad treatment categories most ranged between 0.92 to 1.0 (Table 4). The data revealed high homogeneity as per local people for all treatments. Immuno-regulatory category was assigned the value 1 due to presence of only one taxa in the particular category. Apart from this, hepatic health care and urogenital categories obtained the value of 0.98 indicating a well-defines criteria among the local population and non-random selection of species for the ailment category. Asparagus recemosus, Glycine max, Hordium vulgare, Polygonatum cirrhifolium, Punica granatum, Rephanus sativus and Urtica dioica not only used in hepatic health care but also provide nutritive benefits and warm-potency particularly at higher altitude areas. These species are commonly used in daily food habit of the local community. Also, a higher value of $F_{i c}$ verifies the distribution of the different species used for a specific ailment. The urogenital category, with only 4 taxa included comes second in terms of $\mathrm{Cl}$ as there is a widely accepted notion of using these species for such disorders. The higher value of informant consensus factor for all the ailment categories also imply that the documented species are the most commonly used thin traditional healing system.

The gastrointestinal ailments comprised of 695 use reports from the total categories with a medicinal importance index value of 30.22 (Table 4). Some most sought species in this category are Cannabis sativa, Citrus aurantifolia, Angelica galuca, Ajuga parviflora, and Emblica officinalis. These species are placed in accordance with their use reports mentioned during data collection. In the category of general health care, 22 species are being used with 524 numbers of use-reports \& medical importance of 23.82. The species indicated with the highest number of use-reports are Ocimum basilicum, Citrus aurantifolia, Curcuma longa, Ajuga parviflora and Picorhiza kurrooa on the basis of user reports. Dermatological category ranks third with 21 taxa in use and use report value of 617 and medicinal importance of 29.82. The main species employed for this category on the basis of use reports are Setaria italica, Eupatorium adenophorum, Artemisia martima. Although the hepatic health cure category comprised of only 8 taxa, it has a medicinal importance index values of 45.50 , which is highest of all the categories since the species used under the category are of daily usage and are often included in daily food products with nutritive values. The species include Glycine max, Hordium vulgare, Punica granatum, Urtica dioica, Polygonatum cirrhifolium etc. In other works carried out in Uttarakhand, they were reported these medicinal plants and use different plant parts in different ratio to cure disease or aliments [16,21-23,25,27,28,46-48].

A correlation analysis was done among RFC, $\mathrm{Cl}$, UR, number of species used in treating different ailments, Informant consensus factor $\left(F_{i c}\right)$ and Medical Importance. No evidence of any correlation was observed in most of the parameters, a highly positive correlation was 
only observed in Number of taxa used and number of use reports (0.963). Also, there has been a moderately positive correlation observed between $F_{i c}$ and RFC which is of no significance in the study as both the parameters have been described differently.

Some species are also used in ethnoveterinary purposes for curing domestic animals. Ajuga parviflora is used to cure throat infection, Coriandrum sativum against poison, Taraxacum officinale, Verbascum thapsus and Viola canescens to increase lactation in milching animals.

\section{Weakening of traditional ethnobotanical knowledge}

It is alarming to note that there has been continued decline in traditional ethnobotanical knowledge in the target area (Fig.7). An analysis of community perception on change in use pattern of medicinal plants in 2018 and a decade earlier (i.e. 2008) revealed that there are less number of species used for curing different ailments in recent years (Table 5). People are moving away from traditional herbal cure system and the young generation has no interest in the traditional customs and values. Earlier the people of remote areas preferred to consult with Vaidyas for primary healthcare but for last one decade since there is an increase in accessibility, availability and affordability towards the allopathic medicinal system, the local community is also opting for such options. Despite of that $57 \%$ of the total respondents believe that these plants are highly effective, $30 \%$ found moderately effective, while only $13 \%$ feel it less effective (Fig.

8). Interestingly, to cure selective diseases in children, such as Juga (removal of Ascaris), Chupad (heavy cough), and Kasar (constipation) still people prefer traditional cure system as it has no side effects. During the study it was observed that the Vaidyas do not share their knowledge, they believed that the treatment will not be effective if they share the knowledge with anybody. In the changing lifestyle and socioeconomic scenarios, most of the inhabitants are reluctant to live with their traditional heritage leading to the vanishing of the knowledge [50].

\section{Conclusion}

Community knowledge on use and management of wild plant resources has always been integral to the survival, sustenance and adaptation of human cultures $[46,50,56]$. This study revealed 70 medicinal plant species being used by local marginal community of which 21 are most extensively used species to treat various ailments. The significance of traditional herbal healing system is highly relevant due to its effectiveness. It is cost effective and based on local resources, and still only means of cure for marginal communities in remote localities. Uttarakhand and with population growth and lack of health care there is a need to adhere to the locally available resources to be utilized for general health care and provisioning of suitable side-effect free treatment to the communities. The community still use these species, however the level of use is decreasing in view of upcoming modern allopathic based health-care services. At the same time there is also a decline in number of local Vaidhyas and herbal practitioners. This is because increased access to modern hospitals and medicinal facilities in recent times. This possess significance challenge to the continuity of traditional herbal cure system. The impoverishment of such knowledge may lead to an enormous loss to the scientific community. The ethnomedicinal knowledge and information provided in this study is of significant value for scientific validation, product development, conservation and policy planners for sustainable management of medicinal plants and traditional herbal cure system. It is suggested to explore and establish linkage between traditional health practices and modern health-care systems. It can be done by testing bioactive compound and biological activity of most preferred plant species, and assessing safety and efficacy of local herbal formulation. Such an investigation may lead to many new and novel drug discovery. It is also recommended that the natural habitats of medicinal plants should be protected for conservation of valuable gene pool and to control over exploitation of species. Since ethnomedicinal information is strongly linked to local livelihoods, culture and environment, it is strongly recommended to further continue studying the subject so as to serve the humanity with healthier and operative health care measures.

\section{Acknowledgement}

We owe our gratitude to the people of Garur-Ganga valley and Saryu valley of district Bageshwar, Uttarakhand who shared the valuable information and knowledge. The authors thankfully acknowledge the facilities received from GBPNIHE, Kosi-Katarmal, Almora, India for undertaking this work. We are thankful to DST, Govt. of India for the financial assistance provided under a NMSHE, Task Force 5 sponsored project entitled "Network program on the convergence of traditional knowledge system for sustainable development in the Indian Himalayan Region". We sincerely thanks Dr Deepshikha Arya, Research Officer, CCRAS-RARI, Ranikhet for her support to help in identifying the plant species, as well as Prof. S.C. Garkoti, JNU for his constant support and cooperation.

\section{References}


1. Kala CP. Medicinal plants conservation and enterprise development. Med Plants. 2009; 1(2):79-95.

2. Gupta KK, Khandelwal G, Prasad G, Chopra, AK, Mishra A. A review on scientific technologies in practice to innovate plant based molecules and to improve herbal drug quality to overcome health problems. J Applied and Natur Sci. 2010; 2(1):165-181.

3. Kala CP, Dhyani PP, Sajwan BS. Developing the medicinal plants sector in northern India: challenges and opportunities. J EthnobiolEthnomed. 2006; 2(1):32.

4. Caniago I, Siebert S. Medicinal plants ecology, knowledge and conservation in Kalimantan, Indonesia. Econ Bot. 1998; 52:229-250.

5. Siahsar B, Rahimi M, Tavassoli A, \&Raissi A, Application of biotechnology in production of medicinal plants. Am Eurasian J Agric Environ Sci. 2011; 11(3):439-444.

6. Rossato SC, Leitao-FilhoH,Gegossi A. Ethnobotany of Caicaras of the Atlantic forest coast (Brazil). Econ Bot. 1999; 53:387-395.

7. Hanazaki N, Tamashiro JY, Leitao-FilhoH,Gegossi A. Diversity of plant uses in two Caicaras communities from the Atlantic forest coast, Brazil. BiodiversConserv. 2000; 9:597-615.

8. Gazzaneo LR, Paiva de Lucena RF, Paulino de Albuquerque U. Knowledge and use of medicinal plants by local specialists in a region of Atlantic Forest in the state of Pernambuco (Northeastern Brazil). J EthnobiolEthnomed. 2005; 1(1):9.

9. Gaur RD, Sharma J. Indigenous knowledge on the utilization of medicinal plants diversity in Siwalik region of Garhwal Himalaya, Uttarakhand. J Forest Sci. 2011; 27(1): 23-31.

10. Kala CP. Status and conservation of rare and endangered medicinal plants in the Indian trans-Himalaya. Biol Conserv.2000; $93: 371-$ 379.

11. Dhyani PP, Kala CP. Current research on medicinal plants: Five lesser known but valuable aspects. Curr Sci. 2005; 88:335.

12. Kala CP. Current Status of Medicinal plants used by traditional Vaidyas in Uttaranchal State of India. Ethnobotany Research Applications. 2005; 3:267-278.

13. Osmaston AE. A Forest Flora for Kumaun. International Book Distributors, Dehradun, India.1926.

14. Naithani BD. Flora of Chamoli. Botanical Survey of India, Vol. 1 and 2. Dehradun, India. 1985.

15. Kirtikar KR, Basu BD. (1994). Indian Medicinal Plants. Bishan Singh Mahendra Pal Singh, Dehradun. 1994.

16. Gaur RD. Flora of the District Garhwal: North West Himalaya (with Ethnobotanical Notes), (Transmedia, Srinagar, Garhwal), 1999.

17. Phillips O, Gentry AH, Reynel C, Wilkin P, Galvez DBC. Quantitative ethno-medicine and Amazonian conservation. BiodiversConserv Biol. 1994; 8:225-248.

18. Tardio J, Pardo-de-Santayana M. Cultural importance indices: a comparative analysis based on the useful wild plants of southern Cantabria (northern Spain). Econ Bot. 2008; 62(1):24-39.

19. Pardo-de-Santayana M, Tardio J, Blanco E, Carvalho AM, Lastra JJ, San Miguel E, Morales R. Traditional knowledge of wild edible plants used in the northwest of the Iberian Peninsula (Spain and Portugal): a comparative study. J EthnobiolEthnomed. 2007 ; 3:27.

20. Trotter RT, Logan MH. Informant consensus: a new approach for identifying potentially effective medicinal plants. In: Etkin NL, editor. Plants in indigenous medicine and diet: biobehavioural approaches. Bedfort hills, New York: Redgrave Publishers. 1986; 91112.

21. Gangwar KK, Deepali, Gangwar RS. Ethnomedicinal Plant Diversity in Kumaun Himalaya of Uttarakhand, India. Natur Sci. 2010; 8(5): 66-78.

22. Rawat B, Sekar KC, Gairola S. Ethnomedicinal plants of Sunder dhungavalley, Western Himalaya, India-traditional use, current status and future scenario. Indian Forester. 2013; 139(1): 61-68.

23. Singh P, Attri, BL. Survey on traditional uses of medicinal plants of Bageshwar valley (Kumaun Himalaya) of Uttarakhand, India. Intern J Conserv Sci. 2014; 5(2): 223-234.

24. Tewari S, Paliwal AK, Joshi B. Medicinal use of some common plants among people of Garur Block of district Bageshwar, Uttarakhand, India. Octa J Biosci. 2014; 2(1): 32-35.

25. Bhatt D, Arya D, Chopra N, Upreti BM, Joshi GC, Tewari, LM. Diversity of ethnomedicinal plant: A case study of Bageshwar district Uttarakhand. Journal of Medicinal Plants Studies. 2017; 5(2): 11-24.

26. Shandesh B, Chaudhary RP, Quave CL, Taylor RSL. The use of medicinal plants in the transhimalayan arid zone of Mustang district, Nepal. J EthnobiolEthnomed. 2010; 6:14.

27. Kumar M, Mehraj A, Sheikh MA, Bussmann RW. Ethnomedicinal and ecological status of plants in Garhwal Himalaya, India. J EthnobiolEthnomed. 2011; 7:32. 
28. Malik ZA, Bhat JA, Ballabha A, Bussmann RW. Ethnomedicinal plants traditionally used in health care practices by inhabitants of Western Himalaya. J Ethnopharmacolog. 2015; 172: 133-144.

29. Bhat JA, Kumar M, Bussmann RW. Ecological status and traditional knowledge of medicinal plants in Kedarnath Wildlife Sanctuary of Garhwal Himalaya, India. J. Ethnobiol. Ethnomed. 2013; 9: 1.

30. Kunwar RM, Nepal BK, Kshetri HB, Rai SK, Bussmann RW. Ethnomedicine in Himalaya: a case study from Dolpa, Humla, Jumla and Mustang districts of Nepal. J. Ethnobiol. Ethnomed. 2006; 2: 27.

31. Kunwar RM, Shrestha KP, Bussmann RW. Traditional herbal medicine in Far-west Nepal: a pharmacological appraisal. J. Ethnobiol. Ethnomed. 2010; 6: 35.

32. Kunwar RM, Mahat L, Acharya RP, Bussmann RW. Medicinal plants, traditional medicine, markets and management in far-west Nepal. J. Ethnobiol. Ethnomed. 2013; 9: 24.

33. Moore PD. Trials in bad taste. Nature. 1994; 370: 410-411.

34. Keter LK, Mutiso PC. Ethnobotanical studies of medicinal plants used by traditional health practitioners in the management of diabetes in lower eastern province, Kenya. J. Ethnopharmacol. 2012; 139: 74-80.

35. Quave CL, Pieroni AA. Reservoir of ethnobotanical knowledge informs resilient foodsecurity and health strategies in the Balkans. Nature Plants. 2015; 1(2):14021.

36. Mahmood A, Mahmood A, Malik RN, Shinwari ZK. Indigenous knowledge of medicinal plants from Gujranwala district, Pakistan. J Ethnopharmacol. 2013; 148(2):714-23.

37. Bano A, Ahmad M, Hadda TB, Saboor A, Sultana S, Zafar M, Khan MPZ, Arshad M, Ashraf MA. Quantitative ethnomedicinal study of plants used in the skardu valley at high altitude of Karakoram-Himalayan range, Pakistan. J EthnobiolEthnomed. $2014 ; 10(1): 43$.

38. Gurdal B, Kultur S. An ethnobotanical study of medicinal plants in Marmaris (Mugla, Turkey). J Ethnopharmacol. 2013; 146(1):11326.

39. Ahmad M, Sultana S, Fazl-i-Hadi S, Ben Hadda T, Rashid S, Zafar M, Khan MA, Khan MPZ, Yaseen G. An ethnobotanical study of medicinal plants in high mountainous region of Chail valley (district swat-Pakistan). J EthnobiolEthnomed. 2014;10(1):36.

40. Tugume P, Kakudidi EK, Buyinza M, Namaalwa J, Kamatenesi M, Mucunguzi P, Kalema J. Ethnobotanical survey of medicinal plant species used by communities around Mabira central Forest reserve, Uganda. J EthnobiolEthnomed. $2016 ; 12(1): 5$.

41. Umair M, Altaf M, Abbasi AM. An ethnobotanical survey of indigenous medicinal plants in Hafizabad district, Punjab-Pakistan. PloS one. $2017 ; 12(6): e 0177912$.

42. Farooq A, Amjad MS, Ahmad K, Altaf M, Umair M, Abbasi AM. Ethnomedicinal knowledge of the rural communities of Dhirkot, Azad Jammu and Kashmir, Pakistan. J EthnobiolEthnomed. 2019; 15:45.

43. El Amri J, El Badaoui K, Zair T, Bouharb H, Chakir S, Alaoui T. Ethnobotanical study of medicinal plants in the region El Hajeb (Central Morocco). J Res Biol. 2015; 4(8):1568-80.

44. Boudjelal A, Henchiri C, Sari M, Sarri D, Hendel N, Benkhaled A, Ruberto G. Herbalists and wild medicinal plants in M'Sila (North Algeria): an ethnopharmacology survey. J Ethnopharmacol. 2013; 148(2):395-402.

45. Singh H. Importance of local names of some useful plants in ethnobotanical study. Indian J Tradit Knowledge. 2008; 7(2): 365-370.

46. Jain SK. Dictionary of Indian Folk Medicine and Ethnobotany. Deep publications, PaschimVihar, New Delhi; 1991.

47. Pandey K, Pandey S. Indigenous medicines of Raji tribes of Uttarakhand. Indian J Tradit Knowledge. 2010; 9(1):131-133.

48. Joshi M, Kumar M, Bussmann RW. Ethnomedicinal Uses of Plant Resources of the Haigad Watershed in Kumaun Himalaya. J Medicinal and Aromatic Plant Science and Biotechnology. 2010, 4(1):43-46.

49. Tuttolomondo T, Licata M, Leto C, Bonsangue G, Gargano ML, Venturella G, La Bella S. Popular uses of wild plant species for medicinal purposes in the Nebrodi Regional Park (north-eastern Sicily, Italy). J Ethnopharmacol. 2014; 157:21-37.

50. Maikhuri RK, Nautiyal S, Rao KS, Saxena KG. Medicinal plant cultivation and biosphere reserve management: a case study from the Nanda Devi Biosphere Reserve, Himalaya. Curr Sci. 1998; 74(2): 157-163.

51. Samal PK, Dhyani PP, Dollo M. Indigenous medicinal practices of Bhotia tribal community in Indian Central Himalaya. Indian J Tradit Knowledge. 2010; 9(1): 140-144.

52. Samal PK, Shah A, Tiwari SC, Agrwal DK. Indigenous healthcare practices and their linkages with bioresources conservation and socio-economic development in Central Himalayan region of India. Indian J Tradit Knowledge. 2004; 3(1): 12-26.

53. Jalal JS, Garkoti SC. Medicinal plants used in the cure of stomach disorders in Kumaon Himalaya, Uttarakhand, India. Academia J Medicinal Plants. 2013; 1(7): 116-121. 
54. Pandey NC, Bhatt D, Arya D, Chopra N, Upreti BM, Joshi GC, Tewari LM. Diversity of ethnomedicinal plant: A case study of Bageshwar district Uttarakhand. J Medicinal Plants Studies. 2017; 5(2): 11-24.

55. Kumari P, Samant SS, Puri S. Diversity, distribution, indigenous uses and conservation of medicinal plants in central Himachal Pradesh, North Western Himalaya. J Medicinal Plants Studies. 2018; 6(5): 45-68.

56. Singh A, Nautiyal MC, Kunwar RM, Bussmann RW. Ethnomedicinal plants used by local inhabitants of Jakholi block, Rudraprayag district, Western Himalaya, India. J EthnobiolEthnomed. 2017; 13:49.

57. Garbyal SS, Aggarwal KK, Babu, CR. Traditionally used medicinal plants in Dharchula Himalayas ofPithoragarh district, Uttaranchal. Indian J Tradit Knowledge. 2005; 4(2): 199-207.

58. Mehta PS, Negi KS, Ojha SN, Rayal A, Verma SK. Herbal Based Traditional Practices Used by the Bhotias and Gangwals of the Central Himalayan Region, Uttarakhand, India. J. Environ. Nanotechnol. 2013; 2(1): 83-96.

\section{Declarations}

\section{Author Information:}

1. Dr. SaraswatiNandanOjha; Email: ojhasn16@gmail.com

2. DeeptiTiwari; Email: pandeydeepti1990@gmail.com

3. Aryan Anand; Email: aryananand2010@gmail.com

4. Dr. Rakesh Chandra Sundriyal; Email: sundriyalrc@yahoo.com

\section{Institute Name:}

G. B. Pant National Institute of Himalayan Environment, Kosi - Katarmal, Almora - 263643, Uttarakhand, India.

\section{Authors' contributions}

SNO, DT and AA planned and performed the study and field survey, writing the draft manuscript, and analyzed the data and RCY revised the manuscript and data analysis. All authors read and approved the final manuscript.

\section{Competing interests}

The authors declare that they have no competing interests.

\section{Funding}

The study has been funded by Department of Science and Technology, Govt. of India under National Action Plan for Climate Change (NAPCC) through National Mission on Sustaining Himalayan Ecosystems (Task Force 5- Network programme on the convergence of traditional knowledge system for sustainable development in the Indian Himalayan Region).

\section{Availability of data and materials}

The authors already included all data in the manuscript collected during the field surveys. The documented medicinal plant species were deposited at Centre of Socio-economic Development (CSED), GBPNIHE, Kosi-Katarmal, Almora, Uttarakhand.

\section{Ethics approval and consent to participate}

During field work prior consent of the informants was taken conducting these studies. This was done to adhere to the ethical standards of community participation in scientific research.

\section{Consent for publication}

Not applicable.

\section{Competing interests}

The authors declare that they have no competing interests. 


\section{Tables}

Table 1.Quantitative enumeration of ethno-medicinal plants used by marginal hill community of district Bageshwar. 


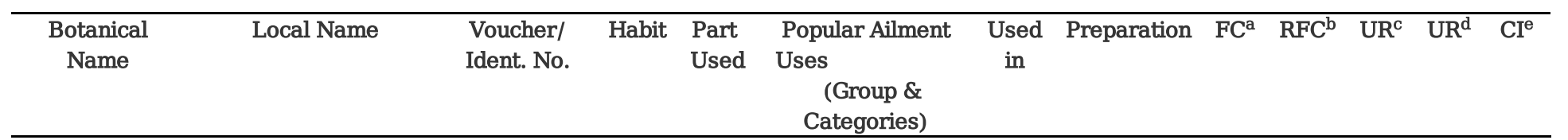

Family: Alliaceae

\begin{tabular}{|c|c|c|c|c|c|c|c|c|c|c|c|c|c|}
\hline $\begin{array}{l}\text { Allium sativum } \\
\text { L. }\end{array}$ & Lasan & GBPCSED1 & $\mathrm{H}$ & $\mathrm{B}$ & $\begin{array}{l}\text { Skeleton } \\
\text { muscles- } \\
\text { Pain (Arth }\end{array}$ & $\begin{array}{r}\text { \& } \\
\text { Joint } \\
\text { s) }\end{array}$ & $\mathrm{Hu}$ & $\mathrm{O}$ & 59 & 0.59 & 59 & 5 & 0.59 \\
\hline
\end{tabular}

Family: Apiaceae

\begin{tabular}{|c|c|c|c|c|c|c|c|c|c|c|c|c|}
\hline $\begin{array}{l}\text { Angelica } \\
\text { glauca Edgew. }\end{array}$ & Gandaraini & RKT 27789 & $\mathrm{H}$ & Rt & $\begin{array}{l}\text { Gastrointestinal- } \\
\text { Stomach ache, } \\
\text { vomiting, } \\
\text { Other - Spices \& } \\
\text { condiment, Herbal } \\
\text { tea }\end{array}$ & $\mathrm{Hu}$ & Co, Inf & 44 & 0.44 & 54 & 89 & 0.89 \\
\hline $\begin{array}{l}\text { Centella } \\
\text { asiatica L. }\end{array}$ & Brahmi & RKT 28186 & $\mathrm{H}$ & $\mathrm{L}$ & $\begin{array}{l}\text { General health } \\
\text { care - Headache }\end{array}$ & $\mathrm{Hu}$ & Po & 28 & 0.28 & 28 & 28 & 0.28 \\
\hline $\begin{array}{l}\text { Coriandrum } \\
\text { sativum L. }\end{array}$ & Dhaniya & RKT 28118 & $\mathrm{H}$ & $\mathrm{Sd}$ & $\begin{array}{l}\text { Antidote - Against } \\
\text { poison }\end{array}$ & $\mathrm{C}$ & Em & 36 & 0.36 & 36 & 36 & 0.36 \\
\hline \multicolumn{13}{|l|}{ Family: Araceae } \\
\hline \multirow[t]{2}{*}{$\begin{array}{l}\text { Acorus } \\
\text { calamus L. }\end{array}$} & Bojh/Buch & RKT 27965 & $\mathrm{H}$ & $\mathrm{Rh}$ & $\begin{array}{l}\text { Skeleton \& } \\
\text { muscles- Sprain, } \\
\text { Inflammation }\end{array}$ & $\mathrm{Hu}$ & $\mathrm{Pw}, \mathrm{O}$ & 55 & 0.55 & 21 & 74 & 0.74 \\
\hline & & & & & $\begin{array}{l}\text { Other - Insect } \\
\text { repellent }\end{array}$ & I & Da & & & 53 & & \\
\hline
\end{tabular}

Family: Asteraceae

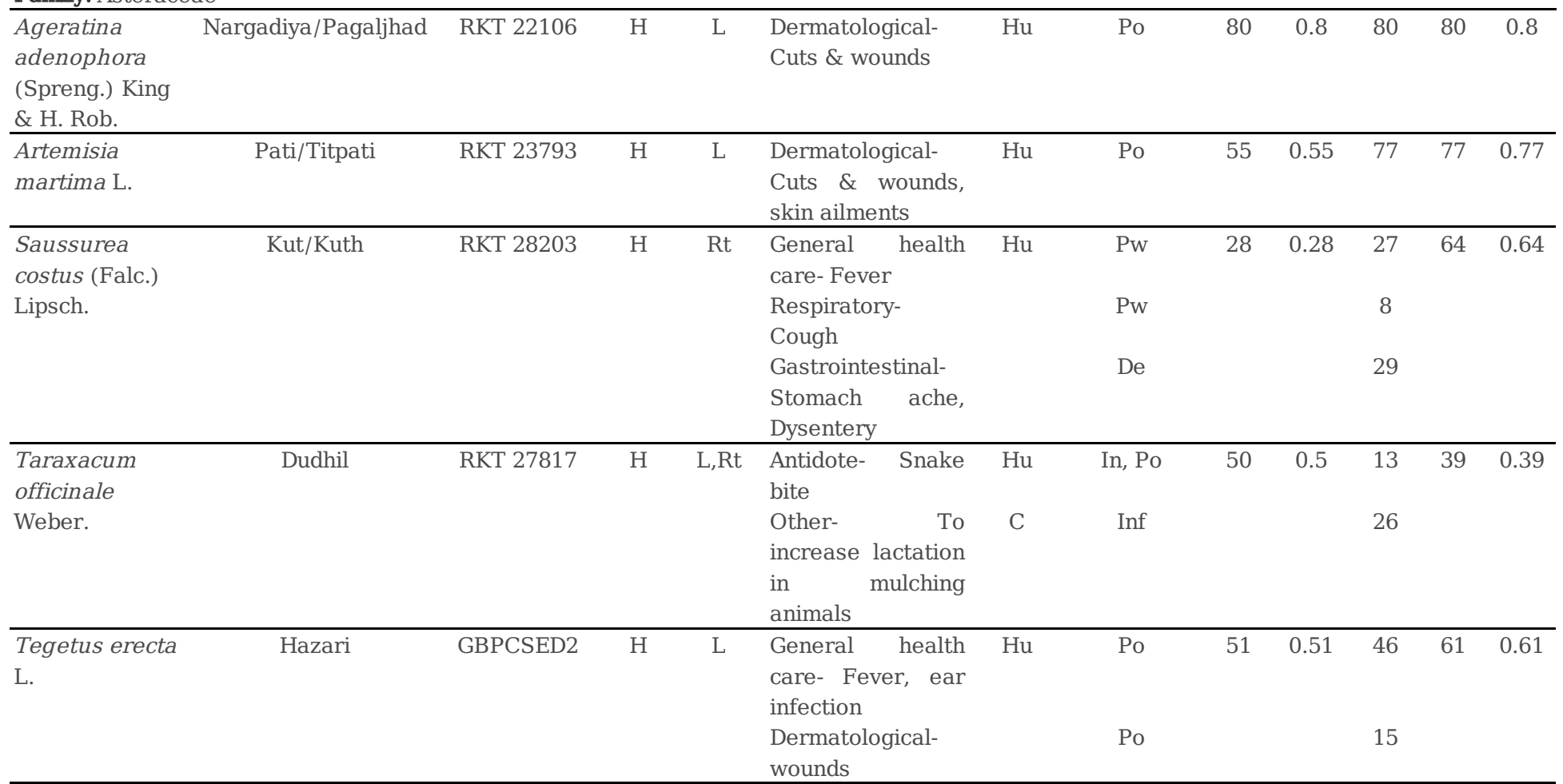

\section{Family:}

Berberidaceae

\begin{tabular}{|c|c|c|c|c|c|c|c|c|c|c|c|c|}
\hline $\begin{array}{l}\text { Berberis } \\
\text { asiatica Roxb. } \\
\text { ex DC }\end{array}$ & Kilmori & RKT 22109 & $\mathrm{~S}$ & Rt & $\begin{array}{l}\text { General health } \\
\text { care - Fever } \\
\text { Circulatory- } \\
\text { Diabetes }\end{array}$ & $\mathrm{Hu}$ & $\begin{array}{l}\mathrm{Pw} \\
\mathrm{Pw}\end{array}$ & 42 & 0.42 & $\begin{array}{l}13 \\
41\end{array}$ & 54 & 0.54 \\
\hline
\end{tabular}

Family: Boraginaceae

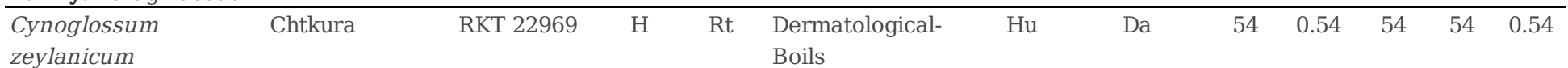

Thunb. Ex

Lehm.

Family: Brassicaceae 


$\mathrm{H}$

$\mathrm{Sd}$,

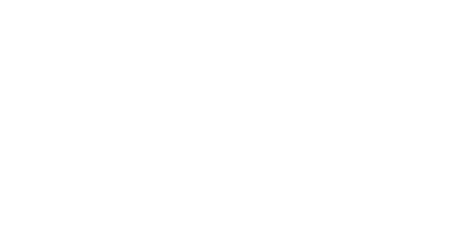

Botanical
Name

Local Name

Voucher/ Habi
Ident. No.

Part

l-

$\mathrm{Hu}$

In

$\begin{array}{lllll}63 & 0.63 & 46 & 94 & 0.94\end{array}$

Purgative

Laxative,

Carminative,

Constipation,

Stomach ache

Antidote- Insect

$\mathrm{Da}$

5

bite

Other- Warm

In, Co

43

effect in winters

\section{Family: Caryophyllaceae}

\section{Drymaria}

Popular Ailment

Used Uses

(Group \&

Categories)

cordata (L.)

$\begin{array}{lllll}\text { RKT } 19989 & \text { H } & \text { WP } & \text { Respiratory- } & H u\end{array}$

In

19

Cough

$\begin{array}{lllllll}\text { Used } & \text { Preparation } & \mathrm{FC}^{\mathrm{a}} & \mathrm{RFC}^{\mathrm{b}} & \mathrm{UR}^{\mathrm{c}} & \mathrm{UR}^{\mathrm{d}} & \mathrm{CI}^{\mathrm{e}}\end{array}$

in

Willd. ex Schult

Silene vulgaris

Pyankura

GBPCSED4

$\mathrm{H}$

WP General health $\mathrm{Hu}$

care- Fever

(Moench)

Gastrointestinal-

Removal

of

Ascaris

(antiparisitic)

locally known as

juga

\section{Family: Combretaceae}

Terminalia

chebula

Harar

(Gaertner)

Retz.

$\begin{array}{cl}\text { RKT 15469 T Fr } & \text { Gastrointestin } \\ & \text { Purgative } \\ & \text { laxative, } \\ & \text { Carminative, } \\ & \text { Constipation, } \\ & \text { Digestive } \\ & \text { problems, } \\ & \text { Diarrhoea }\end{array}$

\begin{tabular}{|c|c|c|c|c|c|c|c|c|c|c|c|c|}
\hline \multicolumn{13}{|c|}{ Family: Cucurbitaceae } \\
\hline $\begin{array}{l}\text { Momordica } \\
\text { charantia L. }\end{array}$ & Karela & RKT 27529 & $\mathrm{Cl}$ & Fr & $\begin{array}{l}\text { Circulatory- } \\
\text { Diabetes }\end{array}$ & $\mathrm{Hu}$ & Co, In & 39 & 0.39 & 39 & 39 & 0.39 \\
\hline \multicolumn{13}{|c|}{ Family: Dioscoreaceae } \\
\hline $\begin{array}{l}\text { Dioscorea } \\
\text { deltoidea } \\
\text { Wall. }\end{array}$ & Genthi & RKT 27301 & $\mathrm{Cl}$ & $\begin{array}{c}\text { Fr } \\
\text { (Atu) }\end{array}$ & $\begin{array}{l}\text { Respiratory- } \\
\text { Cough \& cold }\end{array}$ & $\mathrm{Hu}$ & Co & 32 & 0.32 & 32 & 32 & 0.32 \\
\hline
\end{tabular}

Wall.

Family: Ericaceae

\begin{tabular}{|c|c|c|c|c|c|c|c|c|c|c|c|c|c|}
\hline $\begin{array}{l}\text { Rhododendron } \\
\text { arboreum }\end{array}$ & Burans & RKT 27288 & $\mathrm{~T}$ & $\mathrm{~F}$ & $\begin{array}{l}\text { Hepatic } \\
\text { cure- }\end{array}$ & $\begin{array}{r}\text { health } \\
\text { Liver }\end{array}$ & $\mathrm{Hu}$ & $\mathrm{De}$ & 47 & 0.47 & 64 & 64 & 0.64 \\
\hline
\end{tabular}

Smth complaints, Tonic

Family: Euphorbiaceae

Emblica

officinalis

Gaertn.
Aanwla $\quad$ RKT 21022

Fr C

Circulatory-

Diabetes

Gastrointestinal-

Purgative \&

Laxative,

Carminative,

Stomach ache

Respiratory-

Cough

Other- Source of

vitamin ' $C$ '

Euphorbia

prolifera

Dudhiya, Maikuri

RKT 29216

vitamin '

Ehrenb. Ex.

Boiss

Family: Gentianceae

$\begin{array}{llllll}\text { In } & 35 & 0.35 & 8 & 85 & 0.85\end{array}$

In

54

In

6

In 17

$\begin{array}{llllll}\mathrm{Da} & 7 & 0.07 & 7 & 7 & 0.07\end{array}$




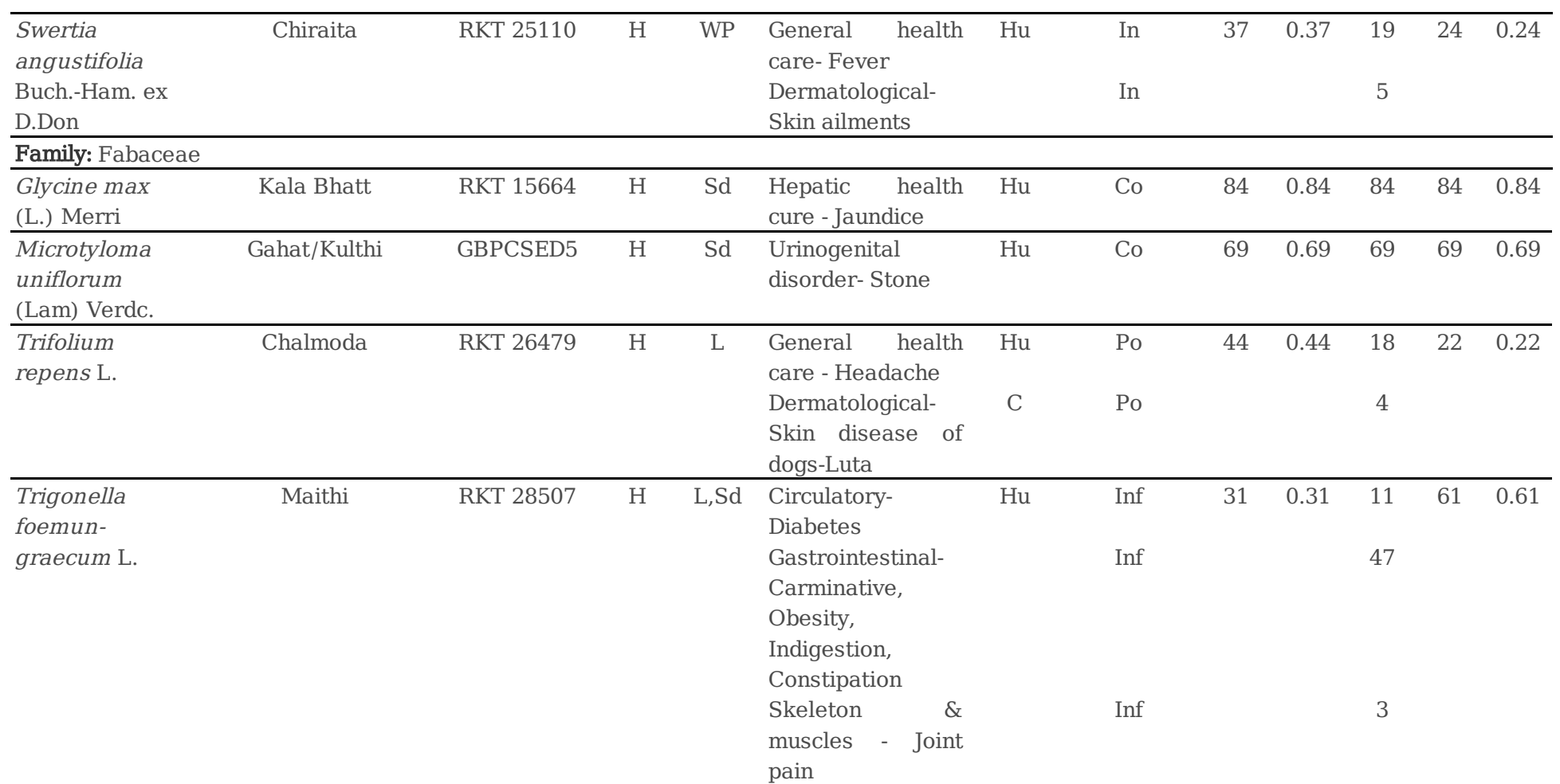

\begin{tabular}{|c|c|c|c|c|c|c|c|c|c|c|c|c|}
\hline $\begin{array}{l}\text { Botanical } \\
\text { Name }\end{array}$ & Local Name & $\begin{array}{l}\text { Voucher/ } \\
\text { Ident. No. }\end{array}$ & Habit & $\begin{array}{l}\text { Part } \\
\text { Used }\end{array}$ & $\begin{array}{l}\text { Popular Ailment } \\
\text { Uses } \\
\text { (Group \& } \\
\text { Categories) }\end{array}$ & $\begin{array}{l}\text { Used } \\
\text { in }\end{array}$ & Preparation & $\mathrm{FC}^{\mathrm{a}}$ & $\mathrm{RFC}^{\mathrm{b}}$ & $\mathrm{UR}^{\mathrm{c}}$ & $U^{\mathrm{d}}$ & $\mathrm{CI}^{\mathrm{e}}$ \\
\hline $\begin{array}{l}\text { Vigna mungo } \\
\text { L. (Fabaceae) }\end{array}$ & Mass, Urad & RKT 27199 & $\mathrm{H}$ & $\mathrm{Sd}$ & $\begin{array}{l}\text { Skeleton \& } \\
\text { muscles- Fracture }\end{array}$ & $\mathrm{Hu}$ & In & 61 & 0.61 & 61 & 61 & 0.61 \\
\hline \multicolumn{13}{|c|}{ Family: Lamiaceae } \\
\hline $\begin{array}{l}\text { Ajuga } \\
\text { bracteosa } \\
\text { Wall. ex } \\
\text { Benth. }\end{array}$ & Ratpatia & RKT 25182 & $\mathrm{H}$ & WP & $\begin{array}{l}\text { General health } \\
\text { care- Fever } \\
\text { Gastrointestinal- } \\
\text { Constipation } \\
\text { Urinogenital- } \\
\text { Diuretic }\end{array}$ & $\mathrm{Hu}$ & $\mathrm{De}$ & 55 & 0.55 & $\begin{array}{l}16 \\
3\end{array}$ & 72 & 0.72 \\
\hline $\begin{array}{l}\text { Ajuga parviflora } \\
\text { Benth. }\end{array}$ & Ratpatia & RKT 26408 & $\mathrm{H}$ & Rt & $\begin{array}{l}\text { General health } \\
\text { care- Fever, } \\
\text { Throat infection } \\
\text { in animal } \\
\text { (Galghotu) } \\
\text { Gastrointestinal- } \\
\text { Constipation, } \\
\text { Stomach ache } \\
\text { Urinogenital- } \\
\text { Stone }\end{array}$ & $\begin{array}{l}\mathrm{Hu} \\
\& \mathrm{C}\end{array}$ & $\begin{array}{c}\text { De, In } \\
\text { De }\end{array}$ & 56 & 0.56 & 25 & 87 & 0.87 \\
\hline $\begin{array}{l}\text { Leucas lanata } \\
\text { Benth }\end{array}$ & Nirasi Jhad & RKT 29214 & $\mathrm{H}$ & $\mathrm{L}$ & $\begin{array}{l}\text { Respiratory- } \\
\text { Cough }\end{array}$ & $\mathrm{Hu}$ & $\mathrm{De}$ & 80 & 0.8 & 80 & 80 & 0.8 \\
\hline $\begin{array}{l}\text { Mentha } \\
\text { arvensis L. }\end{array}$ & Pudina & RKT 4355 & $\mathrm{H}$ & $\mathrm{L}$ & $\begin{array}{l}\text { Gastrointestinal- } \\
\text { Stomach ache, } \\
\text { vomiting, }\end{array}$ & $\mathrm{Hu}$ & $\mathrm{De}$ & 43 & 0.43 & 50 & 50 & 0.5 \\
\hline $\begin{array}{l}\text { Micromeria } \\
\text { biflora Benth. }\end{array}$ & -- & RKT 22949 & $\mathrm{H}$ & WP & $\begin{array}{l}\text { General health } \\
\text { care- Fever }\end{array}$ & $\mathrm{Hu}$ & $\mathrm{De}$ & 6 & 0.06 & 6 & 6 & 0.06 \\
\hline $\begin{array}{l}\text { Ocimum } \\
\text { basilicum L. }\end{array}$ & Tulsi & RKT 19325 & $\mathrm{~S}$ & $\mathrm{~L}, \mathrm{Sd}$ & $\begin{array}{l}\text { General health } \\
\text { care- Fever } \\
\text { Respiratory- } \\
\text { Cough \& cold } \\
\text { Other- Herbal } \\
\text { tea, Warm effect } \\
\text { in winters } \\
\end{array}$ & $\mathrm{Hu}$ & $\begin{array}{l}\text { De } \\
\text { De } \\
\text { De }\end{array}$ & 88 & 0.88 & $\begin{array}{l}33 \\
41 \\
23\end{array}$ & 97 & 0.97 \\
\hline $\begin{array}{l}\text { Origanum } \\
\text { vulgare L. }\end{array}$ & Van Tulsi & RKT 29244 & & $\mathrm{~L}, \mathrm{Rt}$ & $\begin{array}{l}\text { General health } \\
\text { care- Fever }\end{array}$ & $\mathrm{Hu}$ & $\mathrm{De}$ & 31 & 0.31 & 15 & 71 & 0.71 \\
\hline
\end{tabular}


Cough \& cold

wounds

Other- Herbal tea

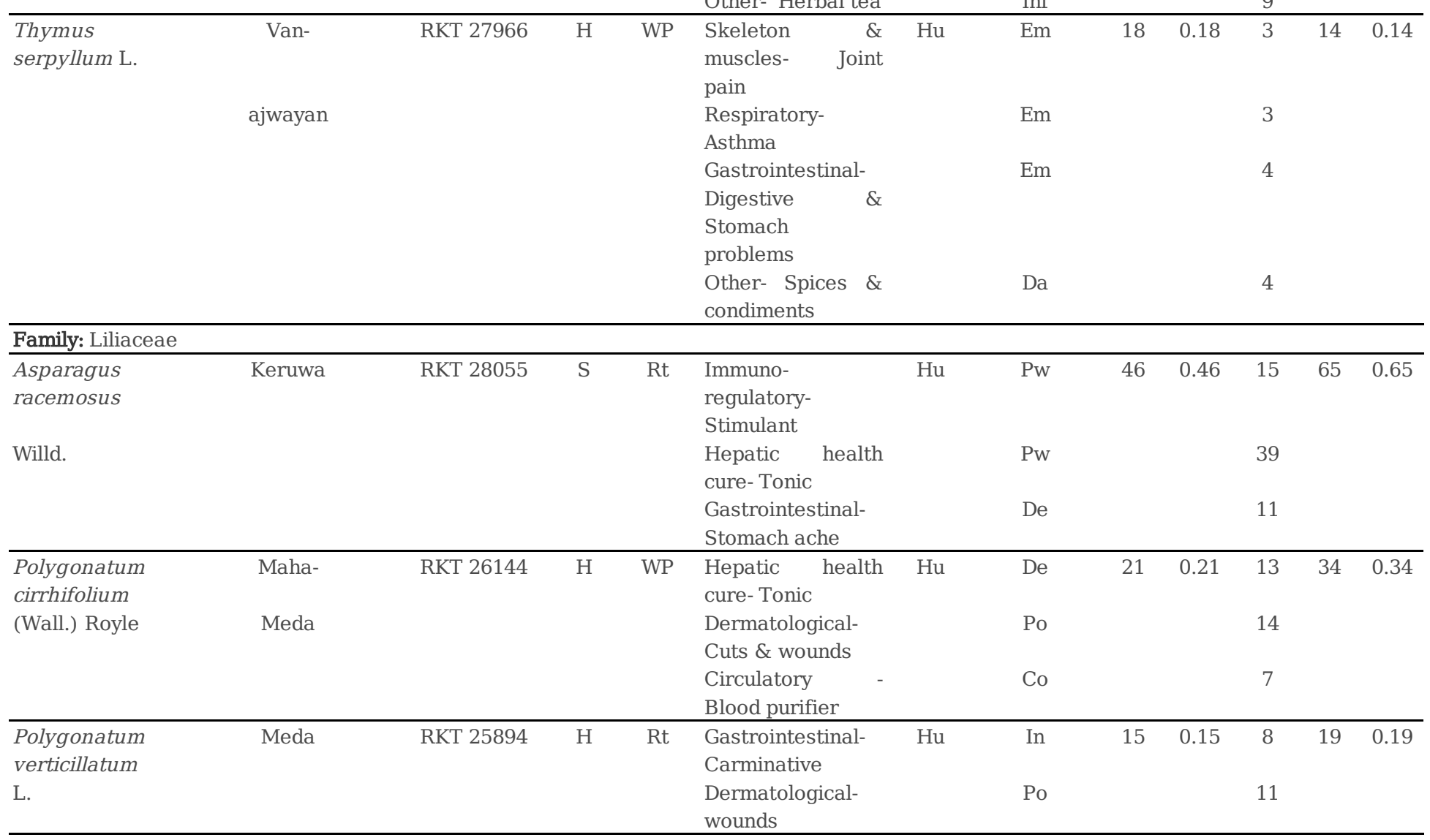

Family: Moraceae wounds

\begin{tabular}{|c|c|c|c|c|c|c|c|c|c|c|c|c|}
\hline $\begin{array}{l}\text { Ficus palmata } \\
\text { Forsk. }\end{array}$ & Bedu & RKT 28094 & $\mathrm{~T}$ & Lt & $\begin{array}{l}\text { Dermatological- } \\
\text { Cuts \& wounds }\end{array}$ & $\mathrm{Hu}$ & $\mathrm{Da}$ & 48 & 0.48 & 39 & 39 & 0.39 \\
\hline \multirow[t]{2}{*}{$\begin{array}{l}\text { Ficus } \\
\text { roxburghii } \\
\text { Wall. }\end{array}$} & Timul & GBPCSED6 & $\mathrm{T}$ & Fr & $\begin{array}{l}\text { Gastrointestinal- } \\
\text { Acidity, } \\
\text { Carminative }\end{array}$ & $\mathrm{Hu}$ & Co & 26 & 0.26 & 45 & 48 & 0.48 \\
\hline & & & & & $\begin{array}{l}\text { Circulatory } \\
\text { Blood pressure }\end{array}$ & & Co & & 0 & 3 & & 0 \\
\hline $\begin{array}{l}\text { Botanical } \\
\text { Name }\end{array}$ & Local Name & $\begin{array}{l}\text { Voucher/ } \\
\text { Ident. No. }\end{array}$ & Habit & $\begin{array}{l}\text { Part } \\
\text { Used }\end{array}$ & $\begin{array}{l}\text { Popular Ailment } \\
\text { Uses } \\
\text { (Group \& } \\
\text { Categories) }\end{array}$ & $\begin{array}{l}\text { Used } \\
\text { in }\end{array}$ & Preparation & $\mathrm{FC}^{\mathrm{a}}$ & $\mathrm{RFC}^{\mathrm{b}}$ & $\mathrm{UR}^{\mathrm{c}}$ & $\mathrm{UR}^{\mathrm{d}}$ & $\mathrm{CI}^{\mathrm{e}}$ \\
\hline
\end{tabular}

\section{Family: Myricaceae}

\begin{tabular}{|c|c|c|c|c|c|c|c|c|c|c|c|c|c|}
\hline $\begin{array}{l}\text { Psidium } \\
\text { guajava L. }\end{array}$ & Amrood & GBPCSED7 & $\mathrm{T}$ & $\mathrm{L}$ & $\begin{array}{l}\text { General } \\
\text { care- } \\
\text { blisters } \\
\text { (astringe }\end{array}$ & $\begin{array}{l}\text { health } \\
\text { Mouth }\end{array}$ & $\mathrm{Hu}$ & In & 12 & 0.12 & 12 & 12 & 0.12 \\
\hline
\end{tabular}

Family: Orchidaceae

\begin{tabular}{|c|c|c|c|c|c|c|c|c|c|c|c|c|}
\hline $\begin{array}{l}\text { Dactylorhiza } \\
\text { hatagirea }\end{array}$ & Salmpanja/ & RKT 26089 & $\mathrm{H}$ & Rt & $\begin{array}{l}\text { Circulatory- } \\
\text { Bleeding }\end{array}$ & $\mathrm{Hu}$ & De & 17 & 0.17 & 17 & 34 & 0.34 \\
\hline (D.Don)Soo & Hattajari & & & & $\begin{array}{l}\text { Dermatological- } \\
\text { Wounds }\end{array}$ & & Po & & & 17 & & \\
\hline
\end{tabular}

Family: Plantaginaceae

\begin{tabular}{|c|c|c|c|c|c|c|c|c|c|c|c|c|}
\hline $\begin{array}{l}\text { Plantago ovate } \\
\text { Forsk. }\end{array}$ & Isabgoal & RKT 1899 & $\mathrm{H}$ & $\mathrm{Sd}$ & $\begin{array}{l}\text { Gastrointestinal- } \\
\text { Constipation, } \\
\text { digestive } \\
\text { problems, } \\
\text { Diarrhoea }\end{array}$ & $\mathrm{Hu}$ & In & 74 & 0.74 & 83 & 83 & 0.83 \\
\hline $\begin{array}{l}\text { Plantago } \\
\text { lanceolata L. }\end{array}$ & Jonkpuri & RKT 8154 & $\mathrm{H}$ & $\mathrm{Rt}$ & $\begin{array}{l}\text { Gastrointestinal- } \\
\text { Removal of }\end{array}$ & $\mathrm{C}$ & In & 43 & 0.43 & 43 & 43 & 0.43 \\
\hline
\end{tabular}


stomach worm of

domestic animals

Family: Poaceae

vulgare $\mathrm{L}$.

Jau

$\begin{array}{llllll}\text { RKT } 26630 & \mathrm{H} & \mathrm{Sd} & \mathrm{Hepatic} & \text { health } \mathrm{Hu}\end{array}$

Co

46

0.46

cure- Warm \&

nutritive effect

Dermatological -

$\mathrm{O}$

17

Setaria italica

Kouni

Burns

L.

RKT 738

Dermatological - $\mathrm{Hu}$

Co

$\begin{array}{lllll}91 & 0.91 & 91 & 91 & 0.91\end{array}$

Measles \&

Chicken pox

Family: Podophyllaceae

\begin{tabular}{|c|c|c|c|c|c|c|c|c|c|c|c|c|}
\hline $\begin{array}{l}\text { Podophyllum } \\
\text { hexandrum }\end{array}$ & Van-Kakri & RKT 27764 & $\mathrm{H}$ & $\begin{array}{l}\text { Fr, } \\
\text { Rt }\end{array}$ & $\begin{array}{l}\text { Dermatological } \\
\text { Wounds }\end{array}$ & . & $\mathrm{Hu}$ & Po & 19 & 0.19 & 19 & $\begin{array}{ll}19 & 0.19\end{array}$ \\
\hline
\end{tabular}

Royle

Family: Polygonaceae

Rheum emodi Dolu

RKT 27793

$\mathrm{H}$

Rt General health $\mathrm{Hu}$

De

31

care - Fever

Dermatological -

Po

$\begin{array}{lll}31 & 0.31 & 15\end{array}$

5

Wounds

Family: Punicaceae

Punica
granatum L.

Darim

$\begin{array}{llllll}\text { RKT } 28845 & \text { T } & \text { Fr } & \text { Respiratory } & \text { - } & \text { Hu }\end{array}$

Cough \& cold

Hepatic health

cure - Anaemia

Other- Source of

vitamin ' $\mathrm{C}$ '

Family: Ranunculaceae

Aconitum Atis

heterophyllum

Wall.

vitamin 'C'

\begin{tabular}{|c|c|c|c|c|c|}
\hline In & 59 & 0.59 & 49 & 71 & 0.71 \\
\hline $\mathrm{De}$ & & & 10 & & \\
\hline De, In & & & 12 & & \\
\hline
\end{tabular}

\section{Ranunculus}

repens L.

Aingadua

RKT 29008

General health $\mathrm{Hu}$

care - Fever

Gastrointestinal - In

Pw

34

0.34

34

vomiting

In 17

Dermatological - $\mathrm{Hu} \quad \mathrm{Po}$

Boils

$\begin{array}{llllll}\text { Po } & 21 & 0.21 & 21 & 27 & 0.27\end{array}$

Gastrointestinal-

In

6

Intestinal pains

(NasPalatana)

\begin{tabular}{|c|c|c|c|c|c|c|c|c|c|c|c|c|}
\hline \multirow[t]{2}{*}{$\begin{array}{l}\text { Thalictrum } \\
\text { foliosum DC. }\end{array}$} & \multirow[t]{2}{*}{ Uppankat hi/Mamira } & \multirow[t]{2}{*}{ RKT 29204} & \multirow[t]{2}{*}{$\mathrm{H}$} & \multirow[t]{2}{*}{ WP } & $\begin{array}{l}\text { Ophthalmic- Eye } \\
\text { infection (White } \\
\text { dot-cataract) }\end{array}$ & $\mathrm{Hu}$ & Inf & 4 & 0.04 & 9 & \multirow[t]{2}{*}{21} & \multirow[t]{2}{*}{0.21} \\
\hline & & & & & $\begin{array}{l}\text { Other- } \\
\text { repellent }\end{array}$ & $\mathrm{I}$ & $\mathrm{Da}$ & & & 12 & & \\
\hline
\end{tabular}

Family: Rosaceae

\begin{tabular}{|c|c|c|c|c|c|c|c|c|c|c|c|c|}
\hline $\begin{array}{l}\text { Duchesnea } \\
\text { indica } \\
\text { (Andrews) } \\
\text { Focke }\end{array}$ & Van Kafal & GBPCSED9 & $\mathrm{H}$ & $\mathrm{L}$ & \begin{tabular}{lr}
\multicolumn{3}{l}{ Dermatological- } \\
Burns re and \\
removal of burn \\
scars
\end{tabular} & $\mathrm{Hu}$ & Po & 3 & 0.03 & 3 & 3 & 0.03 \\
\hline
\end{tabular}

\begin{tabular}{|c|c|c|c|c|c|c|c|c|c|c|c|c|}
\hline $\begin{array}{l}\text { Botanical } \\
\text { Name }\end{array}$ & Local Name & $\begin{array}{l}\text { Voucher/ } \\
\text { Ident. No. }\end{array}$ & Habit & $\begin{array}{l}\text { Part } \\
\text { Used }\end{array}$ & $\begin{array}{l}\text { Popular Ailment } \\
\text { Uses } \\
\text { (Group \& } \\
\text { Categories) }\end{array}$ & $\begin{array}{l}\text { Used } \\
\text { in }\end{array}$ & Preparation & $\mathrm{FC}^{\mathrm{a}}$ & $\mathrm{RFC}^{\mathrm{b}}$ & $\mathrm{UR}^{\mathrm{c}}$ & $\mathrm{UR}^{\mathrm{d}}$ & $\mathrm{CI}^{\mathrm{e}}$ \\
\hline $\begin{array}{l}\text { Prunus persica } \\
\text { Stokes. }\end{array}$ & Aaru & RKT 26465 & $\mathrm{~T}$ & $\mathrm{~L}$ & $\begin{array}{l}\text { General health } \\
\text { care- Headache }\end{array}$ & $\mathrm{Hu}$ & Po & 6 & 0.06 & 6 & 6 & 0.06 \\
\hline $\begin{array}{l}\text { Rosa moschata } \\
\text { Hermm. }\end{array}$ & Kunja & RKT 28695 & S & $\mathrm{L}, \mathrm{F}$ & $\begin{array}{l}\text { Dermatological- } \\
\text { Cuts \& wounds, } \\
\text { boils, } \\
\text { Ophthalmic- Eye } \\
\text { diseases }\end{array}$ & $\mathrm{Hu}$ & Ste & 9 & 0.09 & 27 & 32 & 0.32 \\
\hline \multirow{2}{*}{$\begin{array}{l}\text { Rubus } \\
\text { ellipticus } \\
\text { Smith. }\end{array}$} & Hisalu & RKT 29240 & S & Rt & $\begin{array}{l}\text { General health } \\
\text { care- Fever }\end{array}$ & $\mathrm{Hu}$ & $\mathrm{De}$ & 9 & 0.09 & 9 & 18 & 0.18 \\
\hline & & & & & $\begin{array}{l}\text { Gastrointestinal- } \\
\text { Stomach ache }\end{array}$ & & $\mathrm{De}$ & & & 9 & & \\
\hline
\end{tabular}

Family: Rubiaceae 


$\begin{array}{llllllllllllllll}\begin{array}{l}\text { Rubia } \\ \text { Cordifolia }\end{array} & \text { Manjistha } & \text { RKT } 27933 & \text { H } & \text { Rt } & \begin{array}{l}\text { General health } \\ \text { care- Fever }\end{array} & \text { Hu } & \text { De } & 23 & 0.27 & 23 & 0.23\end{array}$

L.

Family: Rutaceae

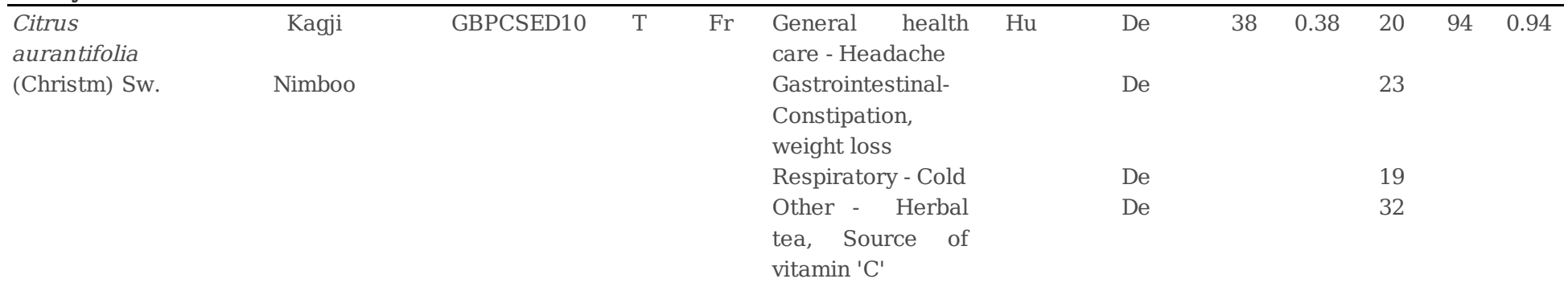

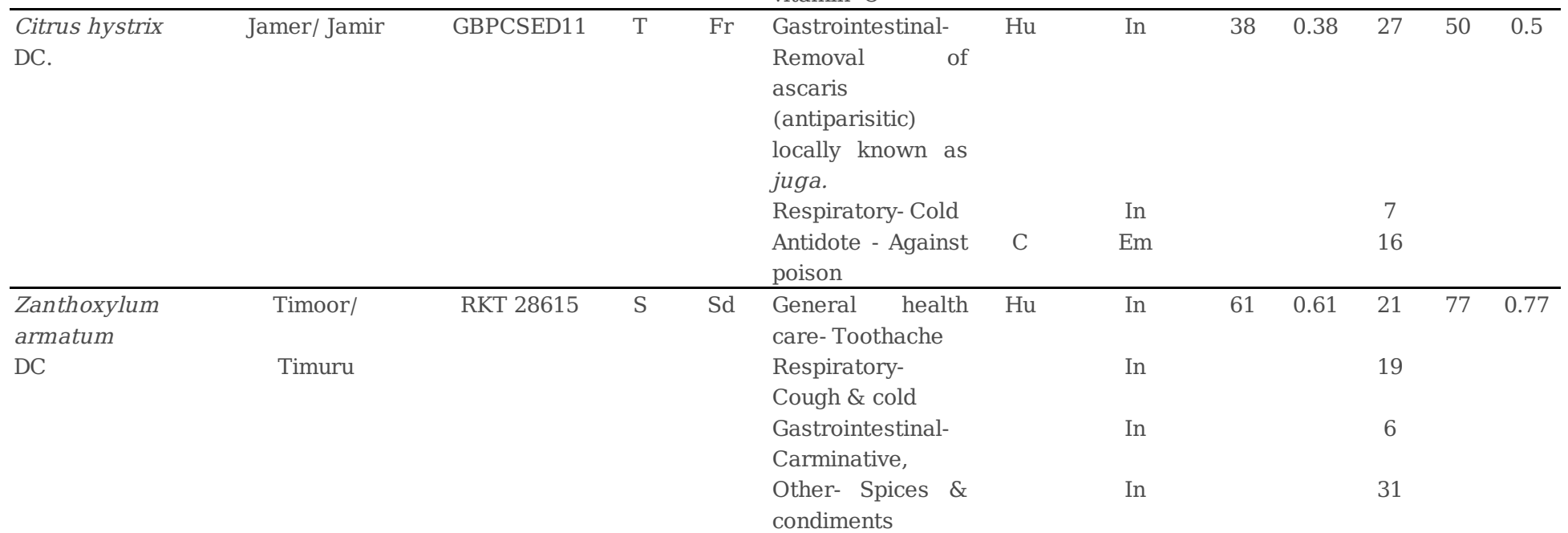

Family: Saxifragaceae

\begin{tabular}{|c|c|c|c|c|c|c|c|c|c|c|c|c|}
\hline $\begin{array}{l}\text { Bergenia } \\
\text { ciliata (Haw) } \\
\text { Sternb }\end{array}$ & Silphora & RKT 25124 & $\mathrm{H}$ & Rt & $\begin{array}{l}\text { Urinogenital- } \\
\text { Urinary infection, } \\
\text { Stone }\end{array}$ & $\mathrm{Hu}$ & Inf, Pw & 51 & 0.51 & 61 & 61 & 0.61 \\
\hline
\end{tabular}

Family: Scorphulariaceae

\begin{tabular}{|c|c|c|c|c|c|c|c|c|c|c|c|c|}
\hline $\begin{array}{l}\text { Picrorhiza } \\
\text { kurrooa Royle. }\end{array}$ & Kutki & RKT 27765 & $\mathrm{H}$ & Rt & $\begin{array}{l}\text { General health } \\
\text { care- Fever } \\
\text { Gastrointestinal - } \\
\text { Abdominal pain }\end{array}$ & $\mathrm{Hu}$ & $\begin{array}{l}\text { In } \\
\text { In }\end{array}$ & 53 & 0.53 & $\begin{array}{l}53 \\
27\end{array}$ & 80 & 0.8 \\
\hline $\begin{array}{l}\text { Verbascum } \\
\text { thapsus L. }\end{array}$ & Akalveer & RKT 27890 & $\mathrm{H}$ & WP & $\begin{array}{l}\text { Dermatological - } \\
\text { Boils } \\
\text { Other- } \\
\text { increase lactation } \\
\text { in To } \\
\text { animals }\end{array}$ & $\mathrm{Hu}$ & $\begin{array}{l}\text { Po } \\
\mathrm{Da}\end{array}$ & 63 & 0.63 & $\begin{array}{l}17 \\
25\end{array}$ & 42 & 0.42 \\
\hline Family: Urticace & & & & & & & & & & & & \\
\hline $\begin{array}{l}\text { Urtica dioica } \\
\text { L. }\end{array}$ & $\begin{array}{c}\text { Shishun/ } \\
\text { Bichhu ghas }\end{array}$ & RKT 22903 & S & $\mathrm{L}$ & $\begin{array}{lr}\text { Skeleton } & \& \\
\text { muscles- } & \text { Joint } \\
\text { pain } & \\
\text { Hepatic health } \\
\text { cure-Warm and } \\
\text { nutritive effect }\end{array}$ & $\mathrm{Hu}$ & Co & 37 & 0.37 & 21 & 52 & 0.52 \\
\hline Family: Violace & & & & & & & & & & & & \\
\hline $\begin{array}{l}\text { Viola } \\
\text { betonicifolia } \\
\text { J.E. Smith } \\
\end{array}$ & $\begin{array}{l}\text { Garurjadi/ } \\
\text { garurabuti }\end{array}$ & GBPCSED12 & $\mathrm{H}$ & WP & $\begin{array}{l}\text { Antidote - Snake } \\
\text { bite }\end{array}$ & $\mathrm{Hu}$ & Po & 12 & 0.12 & 13 & 13 & 0.13 \\
\hline $\begin{array}{l}\text { Viola } \\
\text { canescens } \\
\text { Wall. Ex Roxb }\end{array}$ & Gulovansh & RKT 17561 & $\mathrm{H}$ & WP & $\begin{array}{lr}\text { Other- } & \text { To } \\
\text { increase } & \text { lactation } \\
\text { in } & \text { milching } \\
\text { animals } & \\
\end{array}$ & $\mathrm{C}$ & $\mathrm{Da}$ & 29 & 0.29 & 29 & 29 & 0.29 \\
\hline $\begin{array}{l}\text { Botanical } \\
\text { Name }\end{array}$ & Local Name & $\begin{array}{l}\text { Voucher/ } \\
\text { Ident. No. }\end{array}$ & Habit & $\begin{array}{l}\text { Part } \\
\text { Used }\end{array}$ & $\begin{array}{l}\text { Popular Ailment } \\
\text { Uses } \\
\text { (Group \& } \\
\text { Categories) }\end{array}$ & $\begin{array}{l}\text { Used } \\
\text { in }\end{array}$ & Preparation & $\mathrm{FC}^{\mathrm{a}}$ & $\mathrm{RFC}^{\mathrm{b}}$ & $\mathrm{UR}^{\mathrm{c}}$ & $\mathrm{UR}^{\mathrm{d}}$ & $\mathrm{CI}^{\mathrm{e}}$ \\
\hline
\end{tabular}




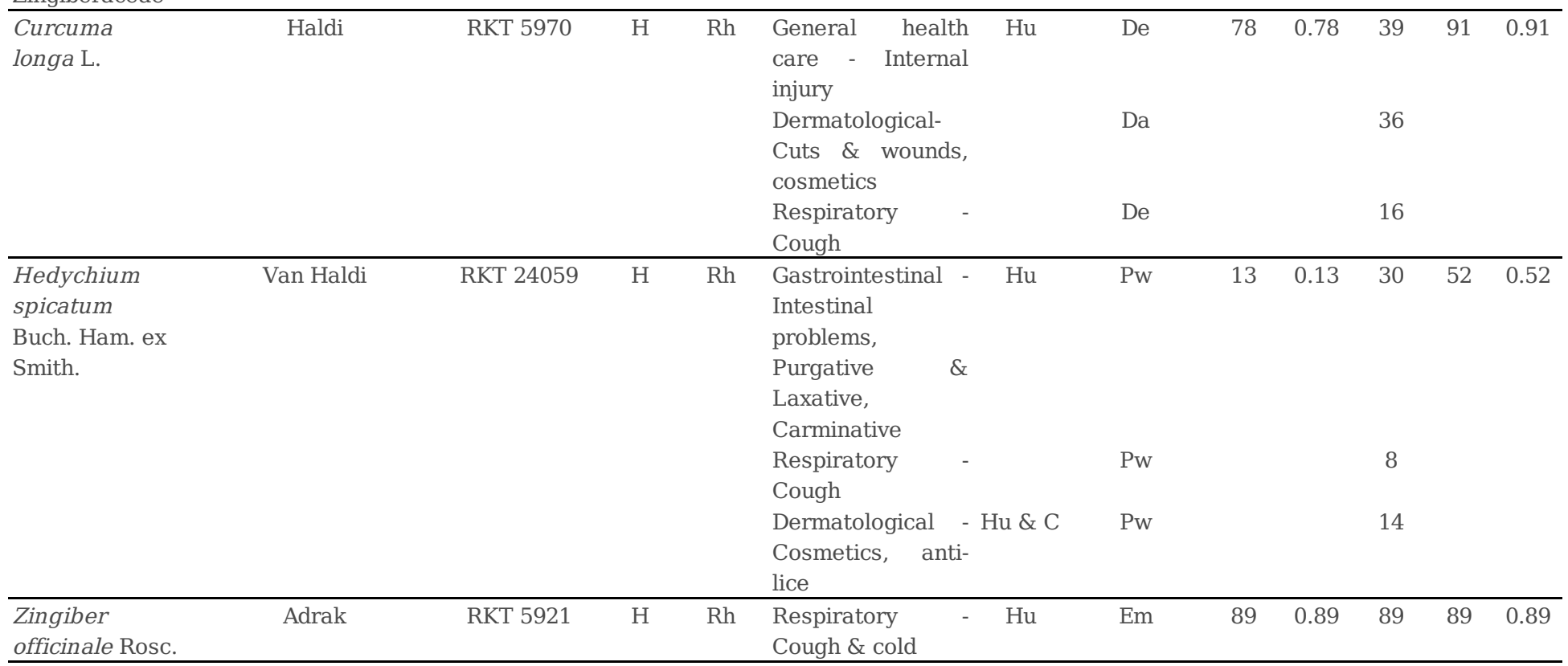

${ }^{\mathrm{a}}$ Use Citation of Taxa (The no. of informants that referred the taxon); ${ }^{\mathrm{b}} \mathrm{RFC}=\mathrm{FC} / \mathrm{N}$, Where $\mathrm{N}$ is the total no. of informants; ${ }^{\mathrm{c}} \mathrm{Use}-\mathrm{reports}$ of the ta ailment category; ${ }^{\mathrm{d}} \mathrm{Use}$-reports of the taxon; ${ }^{\mathrm{e}} \mathrm{CI}=\mathrm{UR} / \mathrm{N}_{\mathrm{t}}$, where $\mathrm{N}_{\mathrm{t}}$ is the total no. of reported taxa;

Aerial tuber(Atu); Bulb (B); Cattle (C); Climber (Cl); Cooking (Co); Decoction (De); Direct application (Da); Emulsion (Em); Flower (F); Fruit (Fr); (H); Insect (I); Infusion (Inf); Ingestion (In); Hour (hr); Human (Hu); Leaves (L); Latex (Lt); Ointment (O); Poultice (Po); Powder (Pw); Rhizome ( Root (Rt); Shrub (S); Seed (Sd); Steam (Ste); Tree (T); Whole Plant (WP).

Table 2. Bio-processing of Medicinal Plants of District Bageshwar. 


\begin{tabular}{|c|c|}
\hline Scientific Name & Mode of administration \\
\hline $\begin{array}{l}\text { Aconitum } \\
\text { heterophyllum } \\
\text { Wall. }\end{array}$ & $\begin{array}{l}\text { Dry root powder (1TS) taken orally with boiled water twice a day for 2-3 days against fever; 1-2 roots chewed to control } \\
\text { vomiting. }\end{array}$ \\
\hline $\begin{array}{l}\text { Acorus calamus } \\
\text { L. }\end{array}$ & $\begin{array}{l}\text { Root powder mixed with grains used as insect repellent, 3-4 dry roots heated with musterd oil applied on the sprain and } \\
\text { inflammatory region. }\end{array}$ \\
\hline $\begin{array}{l}\text { Ageratina } \\
\text { adenophora } \\
\text { (Spreng.) King } \\
\text { \& H. Rob } \\
\end{array}$ & Leaf paste prepared from 100g fresh leaf twigs applied on affected parts for early healing. \\
\hline $\begin{array}{l}\text { Ajuga bracteosa } \\
\text { Wall. ex Benth. }\end{array}$ & Juice of whole plant (10-20 ml) taken twice a day for 2-3 days. \\
\hline $\begin{array}{l}\text { Ajuga parviflora } \\
\text { Benth. }\end{array}$ & $\begin{array}{l}\text { Decoction prepared from } 100 \mathrm{~g} \text { fresh or dried roots with water given 3-5TS orally in fever, stomach ache and constipation for } \\
5 \text { days; this decoction taken orally in empty stomach regularly for stone; } 1-2 \text { leaves chewed on empty stomach for gastric } \\
\text { problem; decoction of whole plant (5-8) crushed with red chilli (3) and } 100 \mathrm{~g} \text { Jiggery (Gur) given twice a day for } 2-3 \text { days to } \\
\text { treat throat infection in domestic animals. }\end{array}$ \\
\hline $\begin{array}{l}\text { Allium sativum } \\
\text { L. }\end{array}$ & Paste prepared from 5-7 Spilled bulb heated with $20 \mathrm{ml}$ mustered oil, massage on joints \\
\hline $\begin{array}{l}\text { Angelica glauca } \\
\text { Edgew. }\end{array}$ & $\begin{array}{l}\text { Root powder (50g) mixed with } 100 \mathrm{ml} \text { water used to control vomiting \& stomach ache; rhizomes are used as spices \& } \\
\text { condiments and tea (as flavour). }\end{array}$ \\
\hline $\begin{array}{l}\text { Artemisia } \\
\text { martima L. }\end{array}$ & Juice $(5-10 \mathrm{ml})$ of fresh leaf applied on the affected area. \\
\hline $\begin{array}{l}\text { Asparagus } \\
\text { racemosus } \\
\text { Willd. }\end{array}$ & $\begin{array}{l}\text { Root decoction }(100 \mathrm{gm}) \text { prepared in water given to cure stomach ache ( } 5 \mathrm{ml} \text { for adult, } 1 \mathrm{TS} \text { for children) for 3-5 days, one } \\
\text { palm full root powder taken with water as stimulant and tonic. }\end{array}$ \\
\hline $\begin{array}{l}\text { Berberis } \\
\text { asiatica Roxb. ex } \\
\text { DC }\end{array}$ & $\begin{array}{l}\text { Root powder (100-150g) taken with warm water given twice a day for } 3 \text { days against fever; fresh or dried roots soaked in } \\
\text { water overnight, filtered and taken orally to cure diabetes in empty stomach. }\end{array}$ \\
\hline $\begin{array}{l}\text { Bergenia ciliata } \\
\text { (Haw) Sternb. }\end{array}$ & $\begin{array}{l}\text { Fresh or dried roots (50-100g) socked overnight and filtered, taken orally in morning for kidey stone. Root powder (50g) } \\
\text { taken with water twice a day for urinary infection. }\end{array}$ \\
\hline $\begin{array}{l}\text { Cannabis sativa } \\
\text { L. }\end{array}$ & $\begin{array}{l}\text { Grinded seeds cooked with some local vegetables (e.g. Colacasia esculanta, Brassica oleracea) for warm effect; broiled } \\
\text { seeds are grinded with salt and green chilli to prepare salt (Pahadi namak), Broiled seeds grinded with Punica garnatum } \\
\text { mixed with green leaves of coriandum, green chilli, salt and sugar to prepare Chatni; Fresh leaves crushed with 3-5 seeds } \\
\text { of black pepper and applied on insect bite. }\end{array}$ \\
\hline $\begin{array}{l}\text { Centella asiatica } \\
\text { L. }\end{array}$ & Fresh leaf paste is applied on forehead. \\
\hline $\begin{array}{l}\text { Citrus } \\
\text { aurantifolia } \\
\text { (Christm) Sw. }\end{array}$ & $\begin{array}{l}\text { Juice extracted from fruit mixed with } 1 \mathrm{TS} \text { honey and } 50 \mathrm{ml} \text { water taken orally in empty stomach for constipation and weigh } \\
\text { loss; lemon tea used in Fever \& Cold. }\end{array}$ \\
\hline $\begin{array}{l}\text { Citrus hystrix } \\
\text { DC. }\end{array}$ & $\begin{array}{l}\text { Fruit juice given orally (1TS) to children for removal of ascaris; cough \& cold } 10 \mathrm{ml} \text { thrice a day; fruit juice with mentha } \\
\text { leaves }(100 \mathrm{~g}) \text { and coriander seeds made into paste given to domestic animals against poison. }\end{array}$ \\
\hline $\begin{array}{l}\text { Coriandrum } \\
\text { sativum L. }\end{array}$ & Seed (80-100g) paste mixed with 1-2 ltr. processed curd (Mattha) is given to domestic animals against poison for 2-3 days. \\
\hline $\begin{array}{l}\text { Curcuma longa } \\
\text { L. }\end{array}$ & Haldi powder $(5 \mathrm{~g})$ mixed with a full glass of warm milk for internal injury; paste of rhizome applied on cuts and wounds. \\
\hline $\begin{array}{l}\text { Cynoglossum } \\
\text { zeylanicum } \\
\text { Thunb. Ex Lehm. }\end{array}$ & Fresh or dried root paste applied on the affected parts \\
\hline $\begin{array}{l}\text { Dactylorhiza } \\
\text { hatagirea } \\
\text { (D.Don)Soo. }\end{array}$ & $\begin{array}{l}\text { Decoction of } 100 \mathrm{gm} \text { root with water taken orally }(10-15 \mathrm{ml}) \text { twice a day for excessive bleeding; root paste applied on } \\
\text { wounds }\end{array}$ \\
\hline $\begin{array}{l}\text { Dioscorea } \\
\text { bulbifera L. }\end{array}$ & Broiled fruit and cooked vegetable. \\
\hline $\begin{array}{l}\text { Drymaria } \\
\text { Cordata (L.). }\end{array}$ & Juice of aerial parts (2-4 drops) taken orally for 2-3 days. \\
\hline Scientific Name & Mode of administration \\
\hline $\begin{array}{l}\text { Duchesnea } \\
\text { indica } \\
\text { (Andrews) } \\
\text { Focke }\end{array}$ & Leaf paste is regularly applied on affected part. \\
\hline $\begin{array}{l}\text { Emblica } \\
\text { officinalis }\end{array}$ & $\begin{array}{l}\text { Fresh fruits are chewed regularly to control diabetes; dried fruits (3-5) boiled with water, filtered and taken orally a } \\
\text { cough, stomach ache; fresh and proceessed fruits are source of Vitamin ' } C \text { '. }\end{array}$ \\
\hline
\end{tabular}

Page 18/27 
Gaertn

Euphorbia sp.

Whole plant (50-100) mixed with FYM.

Ficus palmata $\quad$ Milky latex applied on cuts \& wounds.

Forsk.

Ficus

Fresh fruits are cooked as vegetable.

roxburghii Wall.

Glycine max

(L.) Merri

Bhatt ka Jaula (an indigenous dish) is prepared from paste of seeds (soaked overnight) \& cooked with rice in an iron vessel

"Kadahi".

Hedychium

Dried rhizome powder (2-3g) taken with hot water once a day; paste of fresh rhizome used as anti-lice

spicatum Buch.

Ham. ex Smith.

Hordium

vulgare $L$.

Sattu prepared from $200 \mathrm{~g}$ broiled seeds mixed with $100 \mathrm{~g}$ jaggery (Gur) and $100 \mathrm{~g}$ Ghee for warm and nutritive effect; $50 \mathrm{~g}$

broiled seeds heated with $40 \mathrm{ml}$ mustard oil applied on burns.

\begin{tabular}{l|l} 
Leucas lanata & Leaf juice with 3-5 drops of breast milk taken orally twice a day for one week.
\end{tabular}

Benth

Mentha

arvensis L.

Micromeria

biflora Benth.

Macrotyloma

uniflorum

(Lam) Verdc.

Momordica

charanti L.

Ocimum

basilicum L.

Leaves (100g) boiled with water and filter, the filtrate (50ml) given orally twice a day.

Juice of whole plant with water (1-2 times in a day).

Origanum

vulgare L.

Picrorhiza

Gat

Gahat ka Ras (an indigenous dish) prepared by $150 \mathrm{~g}$ seeds cooked with water (1 ltr.) until the volume reduced (100ml) and taken regularly.

Vegetable and juice (50ml) of fresh fruit taken regularly.

kurrooa Royle.

Plantago ovate

Forsk.

Decoction of $100 \mathrm{~g}$ leaves and seeds, zinger (50g), 5 seeds black paper with $150 \mathrm{ml}$ water taken orally 2-3 times a day for fever, cough \& cold; aerial part used to make herbal tea.

Decoction of $100 \mathrm{~g}$ fresh \& dried leaves with water taken orally (10ml) for a week in cough, cold \& fever; root paste applied on wounds.

Decoction of $50 \mathrm{~g}$ root with water taken orally against fever and abdominal pain for 5-7 days.

\section{Plantego}

lanceolata L.

Podophyllum

hexandrum

Royle

Polygonatum

cirrhifolium

(Wall.) Royle

Polygonatum

verticillatum L.

All

Prunus persica

Stokes.

Psidium

guajava L.

Punica

granatum L.

Ranunculus

repensL.

Rephanus

sativus L.

Rheum emodi

Wall.

Rhododendron

arboreum Smth

Scientific Name

Rosa moschata

Hermm.

Rubia cordifolia

$L$.

Seeds (10g) soaked overnight or consumed directly with water twice a day for 30 days against constipation and digestive problems; Isabgoal (15g) mixed with 10TS fresh curd taken after meal for diarrhoea.

Paste of roots (100g) given to domestic animals.

Root paste applied on wound.

Small pieces of tuber (8-10) soaked in water for overnight, taken in empty stomach for weakness and develop immunity; cooked green leaves eaten as blood purifier; root paste applied on cuts and wounds.

Root powder (50g) is taken with warm water in gastric complaints; fresh root paste applied for wound healing.

Fresh leaf paste applied on head for 2-3 hr.

Fresh leaves are chewed.

Powder (50g) of dried fruit peel taken orally with warm water for old cough; Fruit juice (50ml) given twice a day to anaemic patient.

Root paste (50g) applied for boils and $30-50 \mathrm{ml}$ filtered root extract (juice) is given twice a day against intestinal pain.

Vegetable prepared from fresh leaves and root as salad.

Decoction of $100 \mathrm{~g}$ root with warm water taken orally (10ml) for fever twice a day; root paste applied on wounds.

Juice extracted from fresh flowers

Mode of administration

Fresh leaf paste is applied on cuts, wounds and boils; water extracted from fresh flowers used in eye diseases.

Root decoction with water given orally (1-2TS ) against fever twice a day to children (5 months-10years)

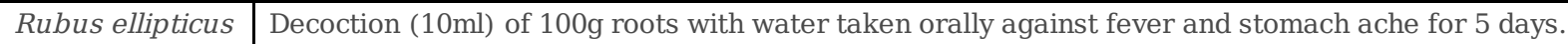

Page 19/27 
Smith.

Saussurea

Decoction of root (50g) with water given against dysentery for 3-5 days twice a day; root powder (50g) taken orally with costus (Falc.)

Lipsch

Setaria italica L. $\quad$ Koni ka Jaula (an indigenous dish) prepared from seeds cooked with water.

Silene vulgaris $\quad$ Root decoction (10ml) with warm water given against fever for 3 days; 1TS is used for removal of ascaris (Juga);leaves are (Moench) Garcke used as a vegetable.

\begin{tabular}{l|l} 
Swertia spp & Juice of fresh leaves (100g) given with boiled water 3TS for 3-5 days for fever; Panchang (whole plant) is used after
\end{tabular} soaking overnight and taken (50-100ml) orally in empty stomach for 15 days.

Taraxacum

officinale

For snake bite: juice of whole plant with water taken orally (1-2TS) thrice a day \& applied on injured part for one week;

Weber. mixture of $100 \mathrm{~g}$ roots with 9 seeds of black pepper, 1-2 ltr. processed curd (Mattha) and $250 \mathrm{~g}$ paste of black soybean given to increase lactation in milching animals

Tegetus erecta

Fresh leaf juice with water taken against fever(3-5 TS twice a day); leaf extract (2-3 drops) in ear infection; fresh leaf paste

L.

Terminalia

chebula

is applied for healing cuts \& wounds.

(Gaertner) Retz.

Thalictrum

foliosum DC.

Thymus

serpyllum L.

Dried fruit powder (100g) given orally with boiled water twice a day for 3-5 days in stomach ache; dried fruit crushed with water and given (1-2 ml) orally to children (3 months to 5 years) and small amount applied around the navel.

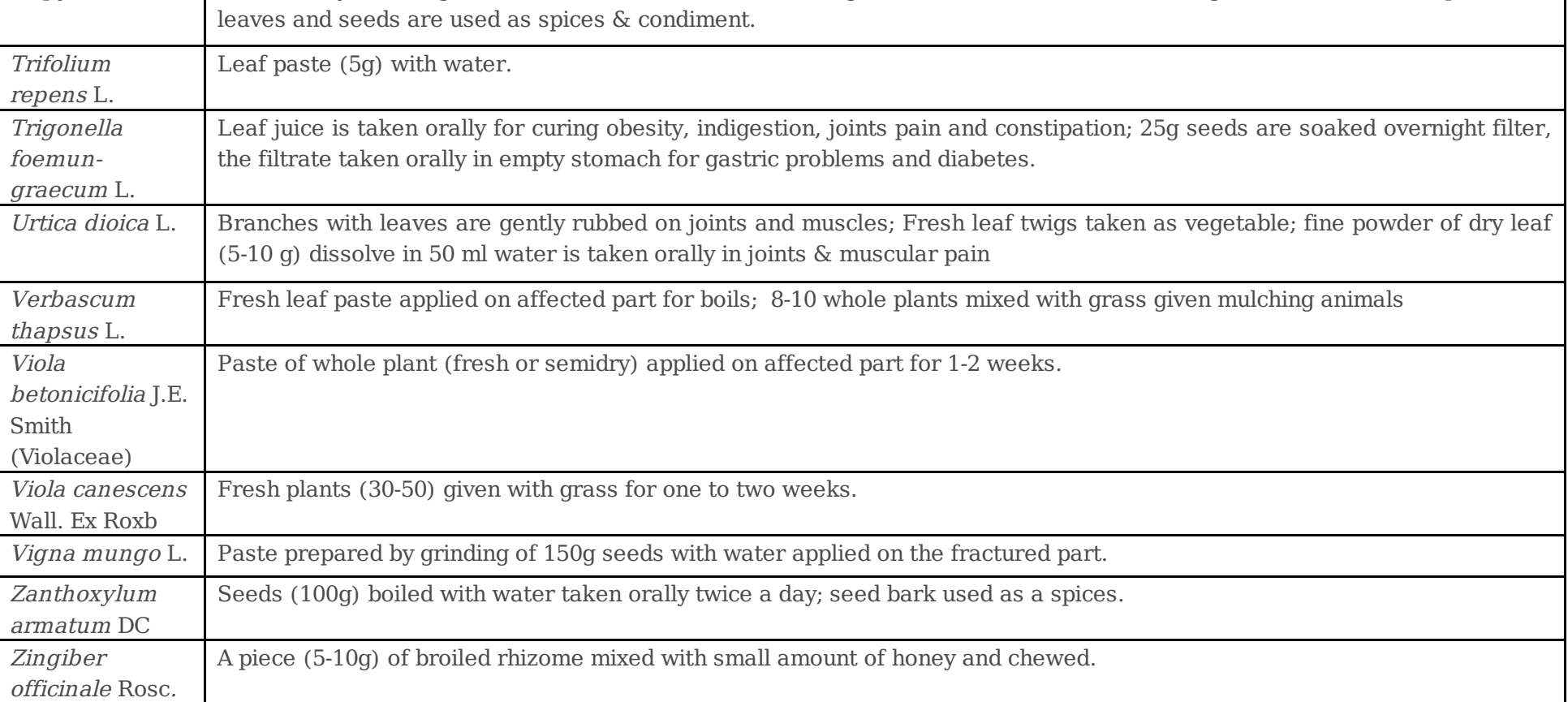

Farm Yard Manure (FYM); Tablespoon (TS);

Table 3. Use value of important ethnomedicinal species of target area 


\begin{tabular}{|c|c|c|c|c|c|}
\hline Taxa & $\mathrm{UR}^{\mathrm{a}}$ & $\mathrm{FC}^{\mathrm{b}}$ & $\mathrm{CI}^{\mathrm{c}}$ & NDAS & Ailments Categories (Decreasing order) \\
\hline Ocimum basilicum L. & 97 & 88 & 0.97 & 5 & Respiratory, general health care and others \\
\hline Cannabis sativa L. & 94 & 63 & 0.94 & 6 & Gastrointestinal, others and antidote \\
\hline Citrus aurantifolia (Christm) Sw. & 94 & 38 & 0.94 & 6 & Others, gastrointestinal, general health care and respiratory \\
\hline Curcuma longa L. & 91 & 78 & 0.91 & 5 & General health care, dermatological and respiratory \\
\hline Setaria italica L. & 91 & 91 & 0.91 & 2 & Dermatological \\
\hline Angelica glauca Edgew. & 89 & 44 & 0.89 & 4 & Others and gastrointestinal \\
\hline Zingiber officinale Rosc. & 89 & 89 & 0.89 & 2 & Respiratory \\
\hline Ajuga parviflora Benth. & 87 & 56 & 0.87 & 5 & General health care, gastrointestinal and urinogenital disorder \\
\hline Rephanus sativus L. & 87 & 87 & 0.87 & 1 & Hepatic health cure \\
\hline Emblica officinalis Gaertn. & 85 & 35 & 0.85 & 6 & Gastrointestinal, others, circulatory and respiratory \\
\hline Glycine max (L.) Merri & 84 & 84 & 0.84 & 1 & Hepatic health cure \\
\hline Plantago ovate Forsk. & 83 & 74 & 0.83 & 3 & Gastrointestinal \\
\hline Ageratina adenophora (Spreng.) King \& H. Rob. & 80 & 80 & 0.80 & 2 & Dermatological \\
\hline Leucas lanata Benth & 80 & 80 & 0.80 & 1 & Respiratory \\
\hline Picrorhiza kurrooa Royle. & 80 & 53 & 0.80 & 2 & General health care and gastrointestinal \\
\hline Artemisia martima L. & 77 & 55 & 0.77 & 3 & Dermatological \\
\hline Zanthoxylum armatum DC & 77 & 61 & 0.77 & 5 & Others, general health care, respiratory and gastrointestinal \\
\hline Acorus calamus L. & 74 & 55 & 0.74 & 3 & Others and skeleton \& muscles \\
\hline Ajuga bracteosa Wall. ex Bent. & 72 & 55 & 0.72 & 3 & General health care, gastrointestinal and urinogenital disorder \\
\hline Origanum vulgare L. & 71 & 31 & 0.71 & 5 & Dermatological, respiratory, General health care and others \\
\hline Punica granatum L. & 71 & 59 & 0.71 & 4 & Respiratory, others and hepatic health cure \\
\hline
\end{tabular}

${ }^{\mathrm{a}}$ Total no. of Use-reports of the taxon; ${ }^{b}$ Use Citation of Taxa (The no. of informants that referred the taxon; ${ }^{\mathrm{c} C I}=\mathrm{UR} / \mathrm{N}_{\mathrm{t}}$, where $\mathrm{N}_{\mathrm{t}}$ is the total no. of reported taxa; No. of different ailment subcategories (NDAS).

Table 4. Informant consensus factor $\left(F_{\mathrm{ic}}\right)$ and medicinal imortance (MI) of Ethno-medicinal plants.

\begin{tabular}{|c|c|c|c|c|c|}
\hline Ailments Category & $\begin{array}{l}\text { No. of Taxa } \\
\left(\mathrm{N}_{\mathrm{t}}\right)^{\mathrm{a}}\end{array}$ & $\begin{array}{l}\text { Frequency } \\
(\%)^{\mathrm{b}}\end{array}$ & $\begin{array}{l}\text { No. of Use -reports } \\
\left(\mathrm{N}_{\mathrm{ur}}\right)\end{array}$ & $\begin{array}{l}\text { Informant consensus factor } \\
\left(F_{\mathrm{ic}}\right)^{\mathrm{c}}\end{array}$ & $\begin{array}{c}\text { Medicinal Importance } \\
(\mathrm{MI})^{\mathrm{d}}\end{array}$ \\
\hline Gastrointestinal & 23 & 32.86 & 695 & 0.97 & 30.22 \\
\hline $\begin{array}{l}\text { General health } \\
\text { cure }\end{array}$ & 22 & 31.43 & 524 & 0.96 & 23.82 \\
\hline Dermatological & 21 & 30.00 & 617 & 0.97 & 29.38 \\
\hline Respiratory & 15 & 21.43 & 402 & 0.97 & 26.80 \\
\hline $\begin{array}{l}\text { Hepatic health } \\
\text { cure }\end{array}$ & 8 & 11.43 & 364 & 0.98 & 45.50 \\
\hline Circultory & 7 & 10.00 & 126 & 0.95 & 18.00 \\
\hline $\begin{array}{l}\text { Skeleton \& } \\
\text { muscles }\end{array}$ & 6 & 8.57 & 178 & 0.97 & 29.67 \\
\hline Antidote & 5 & 7.14 & 83 & 0.95 & 16.60 \\
\hline Urinogenital & 4 & 5.71 & 137 & 0.98 & 34.25 \\
\hline Ophthalmic & 2 & 2.86 & 14 & 0.92 & 7.00 \\
\hline $\begin{array}{l}\text { Immuno- } \\
\text { regulatory }\end{array}$ & 1 & 1.43 & 15 & 1.00 & 15.00 \\
\hline Other & 15 & 21.43 & 377 & 0.96 & 25.13 \\
\hline
\end{tabular}

${ }^{\mathrm{a}}$ No. of species listed in several of the categories of medicinal usage; ${ }^{\mathrm{b}}$ Percentage of records on the total of 70 records; ${ }^{\mathbf{c}_{F}}$ ic $=\left(\mathrm{N}_{\mathrm{ur}}-\mathrm{N}_{\mathrm{t}}\right) /\left(\mathrm{N}_{\mathrm{ur}}{ }^{-}\right.$ 1); ${ }^{\mathrm{d}} \mathrm{MI}=\mathrm{N}_{\mathrm{ur}} / \mathrm{N}_{\mathrm{t}}$.

Table 5. Similarity between present and past ethno-medicinal uses of important species 


\begin{tabular}{|c|c|c|}
\hline Botanical Name & Use Reports in Study Area & Earlier Use Reports from Uttarakhand \\
\hline $\begin{array}{l}\text { Aconitum heterophyllum } \\
\text { Wall. }\end{array}$ & Fever \& Vomiting & Fever, Vomiting and cough $[21,28,51,59]$ \\
\hline Acorus calamus L. & $\begin{array}{l}* \text { Inflammation \& Insect repellent } \\
\text { Sprain }\end{array}$ & $\begin{array}{l}\text { Arthritis, Cancer, Convulsions, Diarrhoea, } \\
\text { Dyspepsia, Epilepsy [21,23]; Sprain [51] }\end{array}$ \\
\hline $\begin{array}{l}\text { Ageratina adenophora } \\
\text { (Spreng.) }\end{array}$ & Cuts \& wounds & Cuts and Wounds $[21,28]$ \\
\hline $\begin{array}{l}\text { Ajuga bracteosa Wall. ex } \\
\text { Benth. }\end{array}$ & $\begin{array}{l}{ }^{*} \text { Constipation } \\
\text { Diuretic, Fever }\end{array}$ & Fevers, Diuretic [21] \\
\hline Ajuga parviflora Benth. & $\begin{array}{l}\text { *Constipation, Stone, Throat infection in } \\
\text { animal (Galghotu) } \\
\text { Fever, Stomach ache }\end{array}$ & Headache, Fever, stomach-ache [54] \\
\hline Allium sativum L. & *Joint Pain (Arthritis) & Mascular pain $[23,52]$; Ear pain $[59]$ \\
\hline Angelica glauca Edgew. & $\begin{array}{l}* \text { Spices \& condiment \& Herbal tea } \\
\text { Stomach ache, Vomiting, }\end{array}$ & $\begin{array}{l}\text { Constipation, bronchitis and stomach } \\
\text { disorders, Vomiting }[23,28,51]\end{array}$ \\
\hline Artemisia martima L. & Cuts, Skin ailments, Wounds & Skin ailments [54] \\
\hline $\begin{array}{l}\text { Asparagus racemosus } \\
\text { Willd. }\end{array}$ & *Stimulant, Tonic \& Stomach ache & Leucorrhoea, Headache, Hysteria, Ulcer, Liver disorders $[21,23]$ \\
\hline $\begin{array}{l}\text { Berberis asiatica Roxb. ex } \\
\text { DC }\end{array}$ & $\begin{array}{l}* \text { Fever } \\
\text { Diabetes }\end{array}$ & Diabetes, Jaundice [21] \\
\hline $\begin{array}{l}\text { Bergenia ciliata (Haw) } \\
\text { Sternb }\end{array}$ & Urinary infection \& Stone & $\begin{array}{l}\text { Fever, Digestive disorders, skin diseases, Urinary infection \& } \\
\text { Stone }[16,28]\end{array}$ \\
\hline Cannabis sativa L. & $\begin{array}{l}\text { *Insect bite, Stomach ache, Purgative \& } \\
\text { Laxative, Warm effect in winters } \\
\text { Carminative, Constipation }\end{array}$ & Analgesic, Cough, Cold, Sedative, Narcotic, Skin diseases [23] \\
\hline Centella asiatica L. & *Headache & Inflammatory infections, Wounds[21, 23] \\
\hline $\begin{array}{ll}\text { Citrus } & \text { aurantifolia } \\
\text { (Christm) Sw. } & \\
\end{array}$ & $\begin{array}{l}\text { Cold, Constipation, Headache, Herbal tea, } \\
\text { Source of vitamin ' } \mathrm{C} \text { ' \& Weight loss, }\end{array}$ & Diarrhoea, Dysentery, Fever, Headache [56] \\
\hline Citrus hystrix DC. & $\begin{array}{l}\text { *Against poison, Cold, Removal of Ascaris } \\
\text { (Anti-parasitic) }\end{array}$ & Vomiting [52] \\
\hline Coriandrum sativum L. & *Against poison & Stomachic and diuretic [23] \\
\hline Curcuma longa L. & $\begin{array}{l}\text { *Internal injury } \\
\text { Cough, Cuts \& wounds \& Cosmetics }\end{array}$ & Skin disorders, Wound healing $[23,52]$ \\
\hline $\begin{array}{l}\text { Cynoglossum zeylanicum } \\
\text { Thunb. ex Lehm. }\end{array}$ & *Boils & Asthma, Bronchitis, Cough, Vomiting, $[16,55]$ \\
\hline $\begin{array}{l}\text { Dactylorhiza hatagirea } \\
\text { (D.Don)Soo }\end{array}$ & Bleeding \& Wounds & Burns, Cuts, Checks bleeding $[21,28]$ \\
\hline Dioscorea deltoidea Wall & Cough \& cold & Cough, Fever Urenogenital disorders, $[21,23,28,54]$ \\
\hline $\begin{array}{l}\text { Drymaria cordata (L.) } \\
\text { Willd. ex Schult }\end{array}$ & *Cough & Laxative [48]; Bile complaints [54] \\
\hline $\begin{array}{l}\text { Duchesnea indica } \\
\text { (Andrews) Focke }\end{array}$ & *Burns and removal of burn scars & Diarrhoea, Fever, Leucorrhoea [55]; Skin diseases [56] \\
\hline Emblica officinalis Gaertn. & $\begin{array}{lcc}\begin{array}{l}\text { Diabetes, } \\
\text { Carminative, } \\
\text { vitamin ' } C \text { ' }\end{array} & \text { Stomach ache \& } & \text { Source of } \\
\end{array}$ & $\begin{array}{l}\text { Asthma, Digestive disorders, Hair fall [28]; Dysentery, Cholera } \\
\text { and Jaundice }[21,54]\end{array}$ \\
\hline $\begin{array}{ll}\text { Euphorbia } & \text { prolifera } \\
\text { Ehrenb. ex Boiss } & \\
\end{array}$ & $*$ Insect repellent & -- \\
\hline Ficus palmata Forsk. & ${ }^{*}$ Cuts \& wounds & Lungs diseases, Skin diseases $[23,48,54]$ \\
\hline Ficus roxburghii Wall. & *Acidity, Source of vitamin 'C' & Laxative [48] \\
\hline Glycine max (L.) Merri & *Jaundice & -- \\
\hline $\begin{array}{l}\text { Hedychium spicatum } \\
\text { Buch. Ham. ex Smith. }\end{array}$ & $\begin{array}{l}\text { Anti-lice, } \\
\text { problems, } \\
\text { Carminative }\end{array}$ & $\begin{array}{l}\text { Carminative, Stomachic, Liver complaints, Fevers, Vomiting, } \\
\text { Diarrhoea, Inflammation, Snake bite }[16,21,54]\end{array}$ \\
\hline Hordium vulgare L. & *Burns, Warm and nutritive effect & -- \\
\hline Botanical Name & Uses Report in Study Area & Earlier Uses Report from Uttarakhand \\
\hline Leucas lanata Benth & *Cough & Cuts, To check bleeding, Wounds [54] \\
\hline Mentha arvensis L. & Stomach ache \& Vomiting, & Diarrhoea, Stomach ache $[53,54]$ \\
\hline Micromeria biflora Benth. & *Fever & Joints pain, Worm infested wounds 21] \\
\hline $\begin{array}{l}\text { Microtyloma } \quad \text { uniflorum } \\
\text { (Lam) Verdc. }\end{array}$ & Stone & Stone $[52]$ \\
\hline
\end{tabular}


Momordica charantia L.

Ocimum basilicum L.

Origanum vulgare L.

Picrorhiza kurrooa Royle. $\quad$ Abdominal pain, Fever

Plantago ovate Forsk.

Plantego lanceolata L.

Podophyllum hexandrum Wounds

Royle

Polygonatum cirrhifolium *Blood purifier, Cuts, Tonic \& Wounds

(Wall.)

Polygonatum verticillatum Carminative \& Wounds

L.

Prunus persica Stokes.

*Headache

Psidium guajava L.

Punica granatum L.

Ranunculus repens L.

Rephanus sativus L.

Rheum emodi Wall.

Rhododendron arboreum

Smth

Rosa moschata Hermm.

Rubia cordifolia L.

Rubus ellipticus Smith.

Saussurea costus (Falc.) Cough, Dysentery, Fever ,Stomach ache,

Lipsch.

Setaria italic L.

Silene

(Moench) Garcke

Swertia angustifolia Buch.- *Skin ailments

Ham. ex D.Don.

\section{Taraxacum}

Weber.

Tegetus erecta L.

Terminalia

(Gaertner) Retz.

Thalictrum foliosum DC.

Fever

Mouth blisters (astringent)

*Anaemia, Cough, Cold, Source of Vitamin 'C'

*Boils \& Intestinal pains (Nas Palatana)

Jaundice

Fever \& Wounds

Liver complaints, Tonic

*Boils, Cuts, Eye diseases, Wounds

*Fever

*Chicken pox \& Measles

vulgaris *Fever \& Removal of Ascaris (Anti-parasitic)

*Snake bite \& To increase lactation in mulching animals

*Ear infection, Fever \& Wounds

chebula Carminative, Constipation,

problems, Diarrhoea, Purgative

*Eye infection (White-dot-cataract), Insect repellent

Botanical Name

Thymus serpyllum L.

Uses Report in Study Area

*Asthma, Joint pain, Spices \& condiments

Digestive \& stomach problems,

Trifolium repens L.

Trigonella

*Headache \& Skin disease of dogs

foemun- Carminative, Constipation,

Indigestion, Joint pain \& Obesity,

*Joint pain, Warm \& nutritive effect

*To increase lactation in milching animals

Boils

Urtica dioica L.

Verbascum thapsus L.

Viola betonicifolia J.E. *Snake bite

Smith

Viola canescens Wall. Ex *To increase lactation in milching animals

Roxb

Vigna mungo L.

*Fracture

Zanthoxylum armatum DC Carminative, Cough \& cold, Toothache, To
Jaundice, Diabetes [23]

Cough, Cold, Fever [16]

Cold, Diarrhoea, Fever, Indigestion, Influenza, Menstrual disorder $[23,54]$

Anemia, Asthma, Blood troubles, Inflammation, Jaundice [21];

Fever, Stomach ache [28]; Abdominal pain, Cataract [51,54]

Constipation, Dysentery \& Diarrhoea [21]

Dyspepsia, Sore wounds, Dysentery, Purgative, Mouth disease and chicks [21]

Purgative, Cancer [21]; Wounds [28]

Anaemia, Fever, Bronchitis, General debility[ 54]

Aphrodisiac, Gastric complaints, Nervine tonic, Wound healing $[23,54]$

Ear infection of children [28]; Antipyretic, Brain tonic[ 21]

Mouth blisters [51,59]

Diarrhoea, Dysentery, Piles[21]

$--$

Jaundice [52]

Cuts, Fracture, Wounds [57]

Heart tonic [28], Stomach diseases [21]

Leucorrhoea, Bleeding, Pregnancy termination [16]

Blood purifier, Joints pain, Leucorrhoea, Cuts, Wounds, Insect sting [54]

Blood pressure, Diarrhoea [21]

Asthma, Cough, Dysentery, Fever [53,54]; Abdominal pain [59]

Asthma, Bronchitis [16]

Pneumonia, Cold, Cough, Fever [54]

Headache, acts as a heart tonic and blood purifier [28,59]

Muscular pain, Piles, Ulcer, Wound healing [23]

Asthma, Digestive problems, Diarrhoea, Purgative[16,28]

Gastric trouble, Used to control external parasites[21]

\section{Earlier Uses Report from Uttarakhand}

Laxative, Stomachic [21]; Cough, Epilepsy, Itching \& skin diseases,

Menstrual disorders, Swelling [54]

Astringent [16]

Diabetes, Diabetes, Rheumatism [16,52]

Skin diseases, Boils [21,28]; Bone fracture [54]

Cough, Fever, Rheumatism [21]; Boils Eye cataract [54]

Blood diseases, Cough, Fever, Skin [58]

Cough, Cold, Malaria, Jaundice [23,48 
*New ethno-medicinal use reports documented from study sites.

\section{Figures}

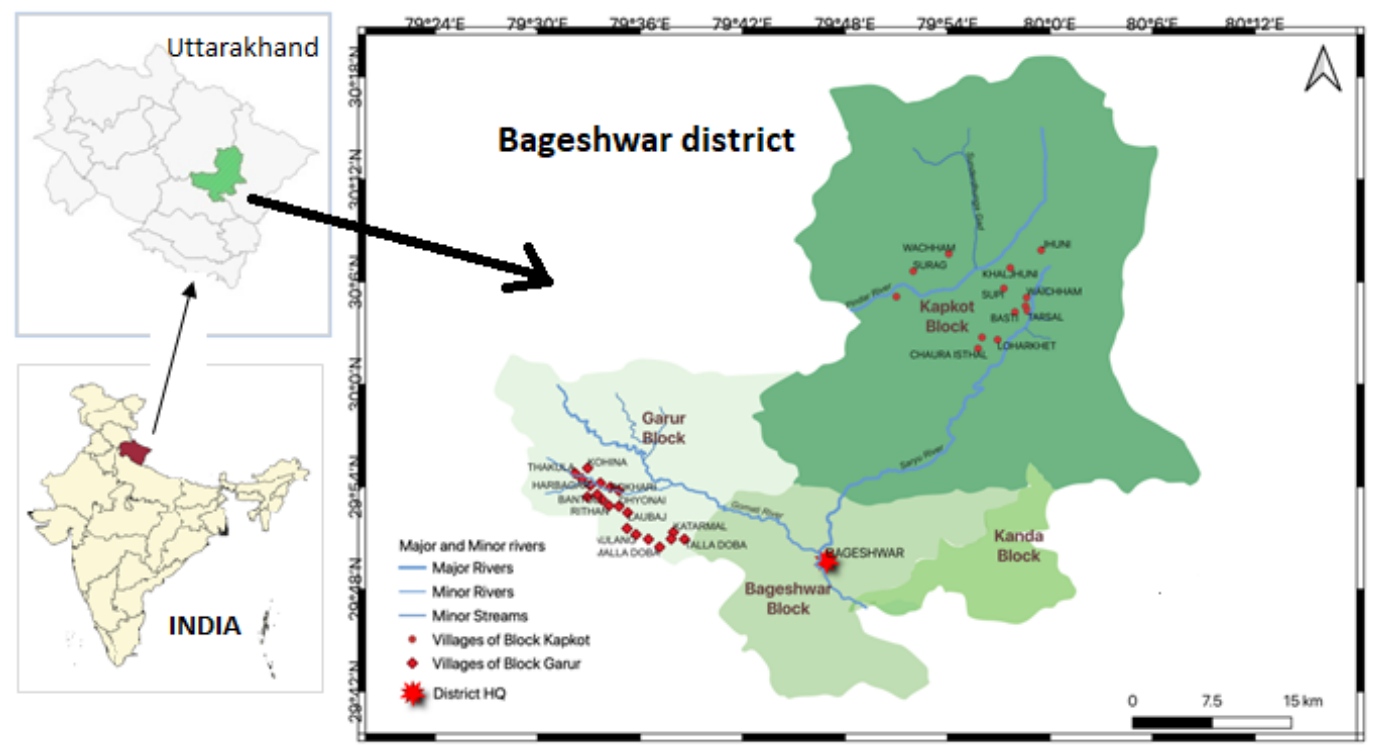

\section{Figure 1}

Study area and villages in Garur and Kapkot Bolcks of District Bageshwar, Uttarakhand, India

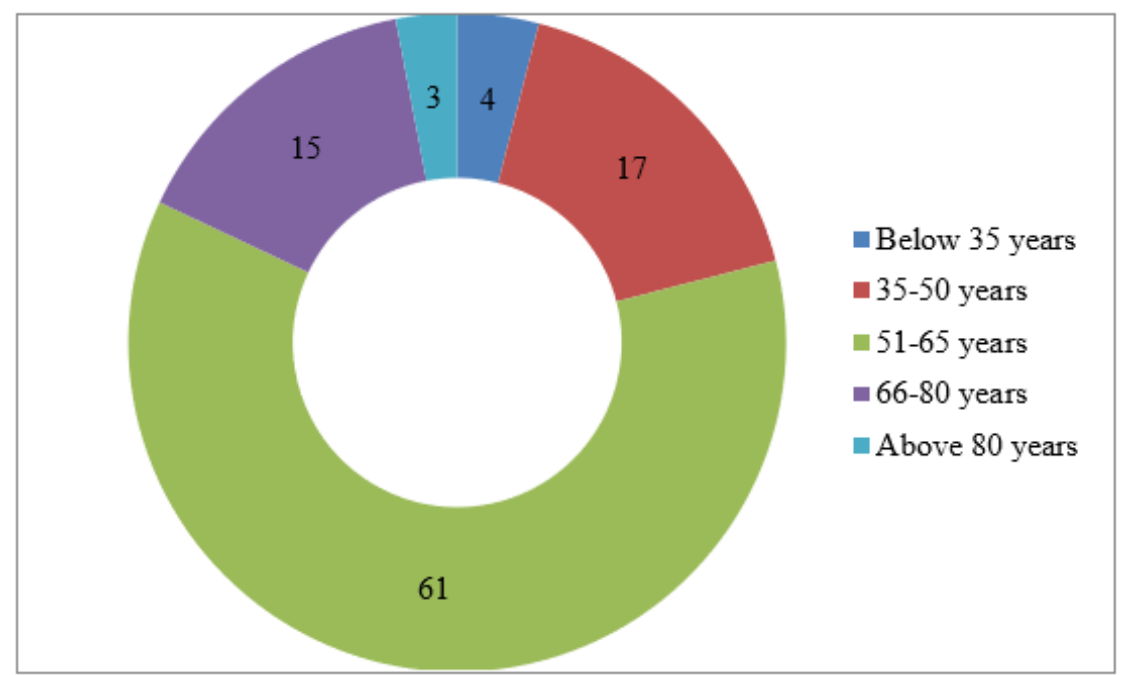

\section{Figure 2}

Age distribution of respondents 


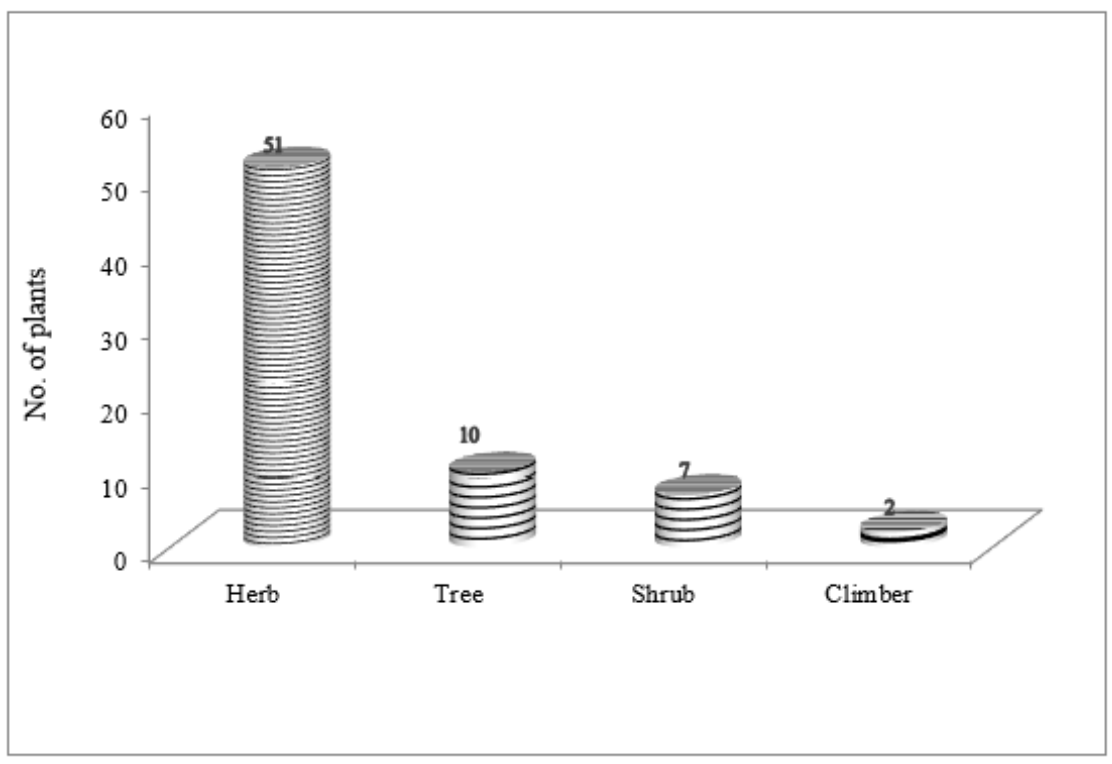

\section{Figure 3}

Distribution of medicinal plants in different life form

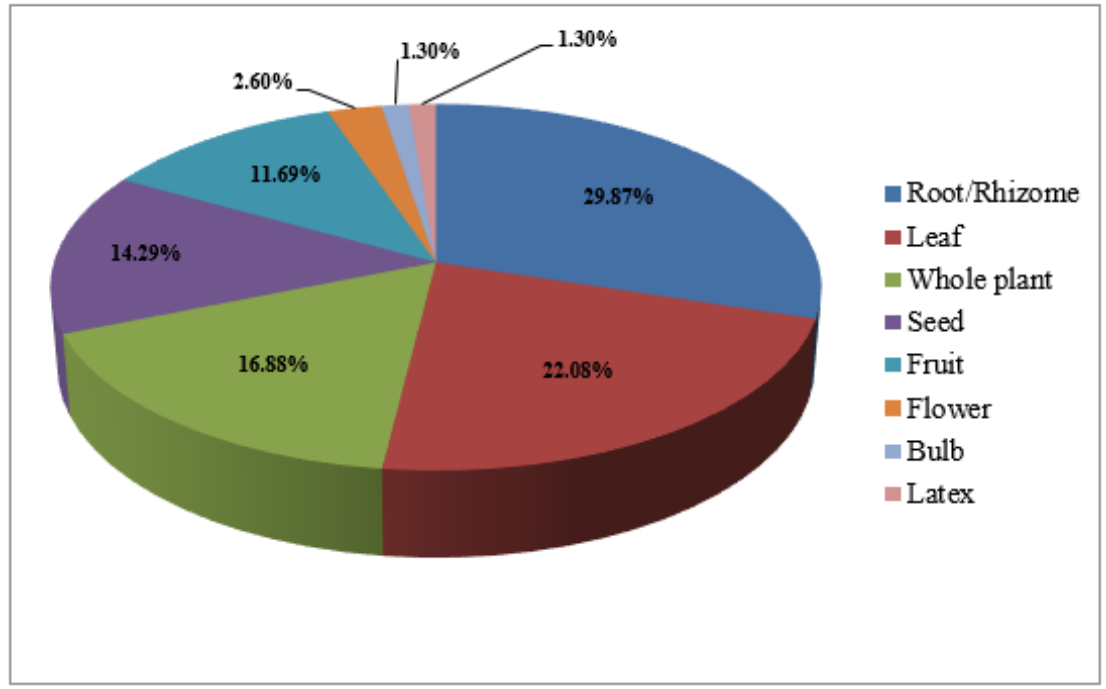

\section{Figure 4}

Plant part used in preparation of medicine 


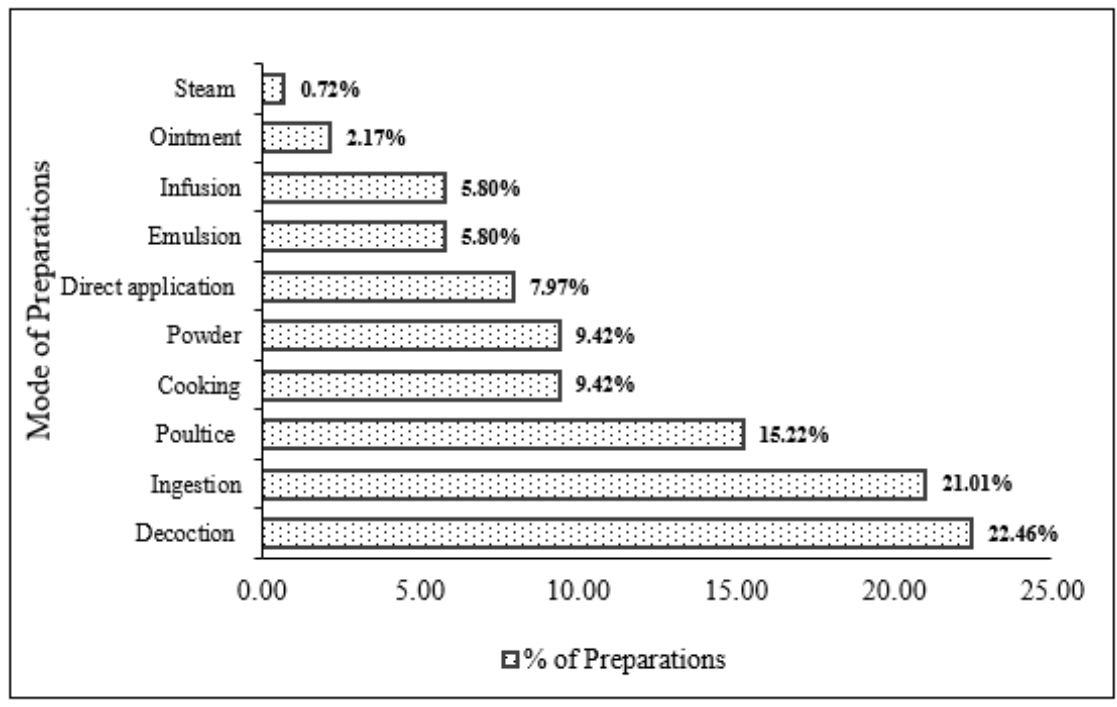

Figure 5

Processing of plant parts in preparation of medicine

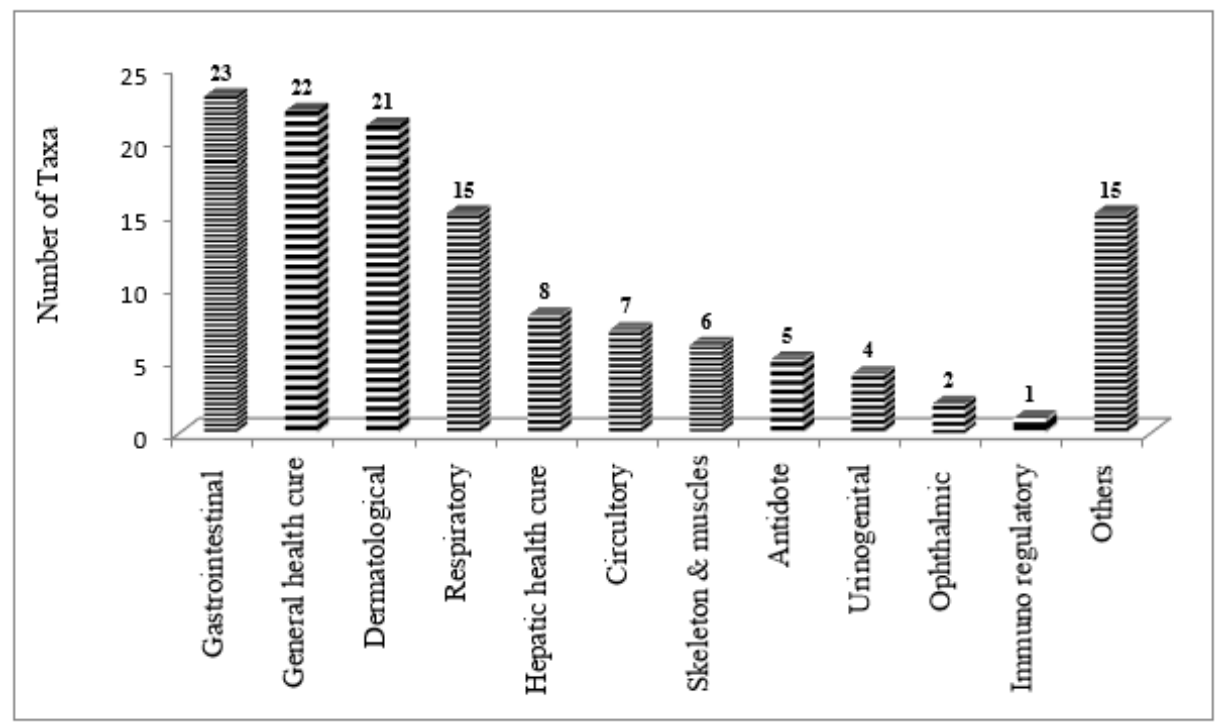

Figure 6

Distribution of medicinal plants in different ailments category

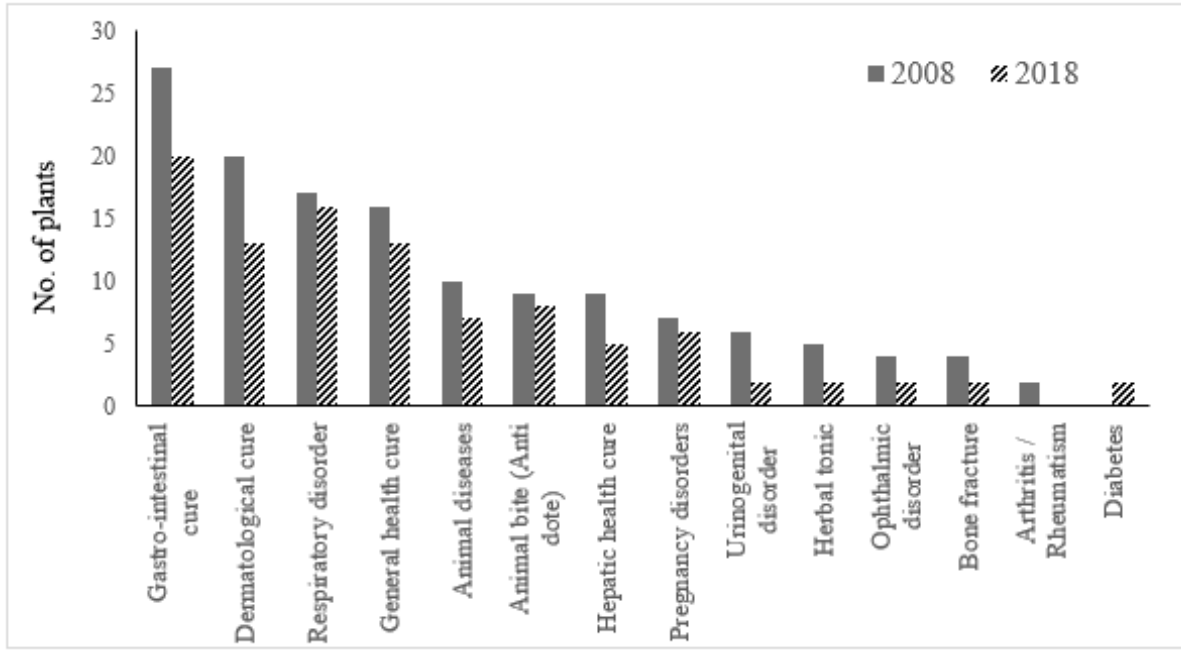




\section{Figure 7}

Past (2008) and present (2018) use of plants in traditional healthcare system

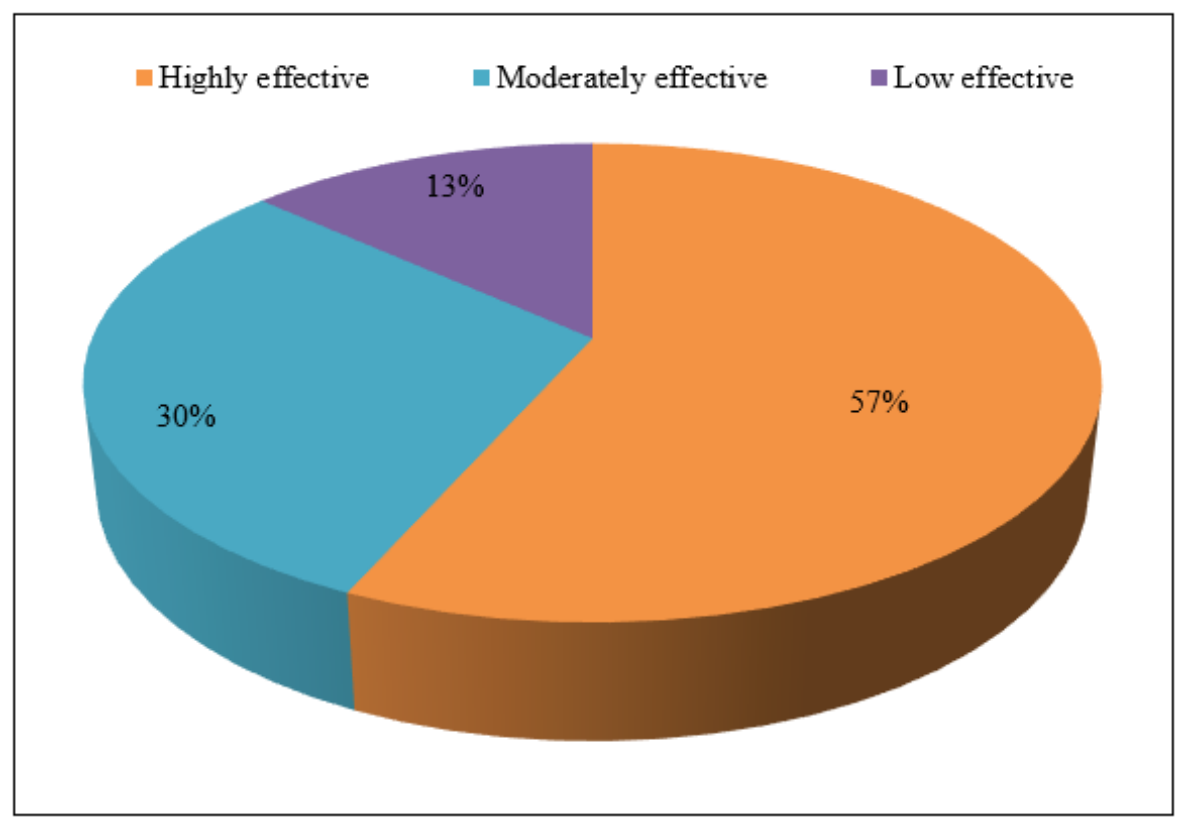

\section{Figure 8}

Community view points on effectiveness of traditional healthcare system 